\title{
Multiple taxes and alternative forms of FDI: evidence from cross-border acquisitions
}

\author{
Nils Herger • Christos Kotsogiannis • \\ Steve McCorriston
}

Published online: 18 March 2015

(C) Springer Science+Business Media New York 2015

\begin{abstract}
This paper explores the role of tax instruments in affecting foreign direct investment (FDI), paying particular attention on their effect on two forms of FDI strategy, 'horizontal' and 'vertical'. Applying a decomposition of FDI strategies to the universe of cross-border mergers (the dominant form of FDI) over the period 1999-2010, it emerges that taxes have a much more nuanced effect on FDI than frequently suggested; while corporate taxes affect FDI negatively, the tax elasticity varies depending on the FDI strategy (with vertical FDI being in general more responsive), the exact measure of taxation, and international tax considerations (double taxation, withholding taxes). Sales taxes also affect FDI, but only horizontally.
\end{abstract}

Keywords Corporate taxation - Cross-border acquisitions - Location choice . Poisson regression $\cdot$ Sales taxes

JEL Classifications $\mathrm{F} 15 \cdot \mathrm{F} 21 \cdot \mathrm{F} 23 \cdot \mathrm{F} 33$

Electronic supplementary material The online version of this article (doi:10.1007/s10797-015-9351-6) contains supplementary material, which is available to authorized users.

\section{N. Herger}

Study Center Gerzensee, Dorfstrasse 2, P.O. Box 21, 3115 Gerzensee, Switzerland

e-mail: nils.herger@szgerzensee.ch

C. Kotsogiannis $\cdot$ S. McCorriston ( $\square)$

Department of Economics, University of Exeter Business School,

Streatham Court, Rennes Drive, Exeter EX4 4PU, UK

e-mail: s.mccorriston@ex.ac.uk

C. Kotsogiannis

CESIfo, Munich, Germany

e-mail: c.kotsogiannis@exeter.ac.uk 


\section{Introduction}

One of the key features of the modern and globalised world is foreign direct investment (FDI). FDI has increased in both absolute terms, and relative to gross domestic product (GDP), over the last few decades, and its importance has spawned a fairly sizeable economics literature that has attempted to explain its nature, causes and consequences, and the distinction between 'horizontal' FDI (where firms duplicate roughly the same activities in multiple countries) and 'vertical' FDI (which involves firms locating stages of production in different countries). However, differentiating between these two forms of FDI has remained an on-going challenge in the empirical literature on FDI.

From a public economics perspective, a broad consensus in the literature that taxes affect FDI has emerged, ${ }^{1}$ but there has been limited empirical evidence on which taxes affect which type of investment, 'horizontal' or 'vertical'? Since the motives behind these strategies differ, contingent on the factors that drive these alternative forms of FDI, the effect of taxes could also differ. The aim of this paper is, therefore, to explore the interaction between FDI strategies and tax policy, with a particular eye to whether international tax system rules matter for both types of investment. It does so by exploiting a large panel with an almost exhaustive coverage of cross-border acquisitions (CBAs) — which has been the dominant form of FDI-across 30 countries and over a decade (1999-2010).

Specifically, this paper makes two contributions. Firstly, and drawing on the work by Fan and Lang (2000), Fan and Goyal (2006), Alfaro and Charlton (2009), Acemoglu et al. (2009), and Garfinkel and Hankins (2011), we differentiate between horizontal and vertical investment strategies. As noted, we use CBA data which has two important advantages: it is the dominant form of FDI (UNCTAD 2000; Giovanni 2005), accounting for as much as $80 \%$ of worldwide FDI in any given year and being particularly important in developed countries (Antràs and Yeaple 2014, p. 66); in addition, the coverage of the location choices embodied in CBAs is extensive, as the data set contains in excess of 80,000 international deals between 1999 and 2010 across 30 countries. $^{2}$ Our second contribution is to derive the tax elasticity associated with alternative FDI strategies and identify which taxes affect which investment decision accounting also (following Barrios et al. 2012) for the effect of international taxation (that is, differences in tax regimes, tax credits and withholding taxes) across countries. The analysis considers also the role of non-profit taxes on the location choices of multinational firms. ${ }^{3}$

\footnotetext{
1 Recent empirical work on the linkages between taxes and foreign direct investment (FDI) has addressed issues relating to the use of statutory, effective average, or effective marginal rates in measuring the impact of corporate income taxation and their role in the location decision of firms (as in, among others, Devereux and Griffith 1998; Devereux et al. 2002; Devereux 2006; Buettner and Ruf 2007), the role of bilateral tax treaties and international double taxation (as in Blonigen and Davies 2004; Huizinga and Voget 2009; Barrios et al. 2012), the role of non-profit taxes (Desai et al. 2004; Buettner and Wamser 2009).

2 As will be noted shortly below, the estimation is performed by a suitably parameterized Poisson regression, which aggregates the location choices into a count variable and hence requires a much lower number of observations for estimation than a model of the (conditional) logit class.

3 Desai et al. (2004) have argued that, whilst international tax competition has lead to an erosion of the tax rates on corporate income, other taxes levied on such things as sales or wage payments have become relatively more important in influencing the decision to invest abroad. Indeed, for the
} 
The results show that the effect of various forms of taxes upon the incentive of multinationals to invest in a foreign country is broadly negative; this is consistent with much of the research on taxes and FDI that arises in the public finance literature. For corporate taxes, the elasticity lies broadly between $-1 / 20$ and $-9 / 20$. The effect of corporate taxes depends on the exact measure of taxation, whether the role of the international tax burden is taken into account, as well as the FDI strategy pursued by the multinational firm. In particular, double taxation - which arises when the same profit is also taxed in the parent country and when withholding taxes have to be paid in the host country when repatriating profits - increases the detrimental effect of corporate taxes on FDI. For sales taxes, the elasticity is around $-1 / 4$ but the effect arises primarily with FDI that is driven by a horizontal strategy, where an affiliate is integrated into the multinational enterprise to access the local market. Conversely, no significant effect on the sales tax could be found with vertical FDI, which involves subsidiaries producing export goods, on which the sales tax can normally be reimbursed at the border.

With the extensive coverage of CBAs, the results in this paper differ from the extant literature: the estimated tax elasticity is lower than generally reported elsewhere but it also differs according to the underlying motivation for FDI; the effect of taxes depends on how double taxation and withholding taxes are treated with again notable differences between horizontal and vertical FDI; sales taxes do matter but it relates to specific forms of FDI.

The remainder of the paper is organised as follows. Section 2 provides a synoptic overview of the literature to which this paper relates. Section 3 outlines the methodology for identifying alternative strategies for foreign direct investment highlighting the distinction between horizontal and vertical CBAs. Section 4 addresses issues about the relevant tax measure for the MNE accounting for additional parent country and withholding taxes which may play a role in determining FDI. Section 5 presents the location choice framework and discusses the control variables determining a firm's decision to acquire affiliates in foreign countries. Section 6 reports the results. Section 7 summarises and concludes.

\section{Related literature}

This paper is connected with the following aspects of the literature on cross-border acquisitions and FDI, the definition of FDI strategies, and the linkages between taxes and FDI.

\subsection{Cross-border acquisitions (CBAs) and foreign direct investment (FDI)}

Discussion of the effects of taxes on FDI usually relies on data relating to FDI flows or stocks or sales from multinational affiliates (De Mooij and Ederveen 2003, 2008). Given data limitations, this has often inhibited a comprehensive coverage of the effects

Footnote 3 continued

case of US multinationals, Desai et al. (2004) present evidence that the importance of direct taxes has been decreasing whilst the indirect tax burden has increased. 
across a large number of countries over a reasonably long period of time. This paper uses data on CBAs which, as noted already, presents two main advantages. First, CBAs are typically the dominant form via which FDI occurs, and second, CBA data are now available across a large number of countries and years. Reflecting this, a growing literature has begun to use CBA data to address FDI questions. Examples include the role of investor protection and accounting rules (Rossi and Volpin 2004), valuation effects in financial markets (Giovanni 2005; Erel et al. 2012), trade costs (Hijzen et al. 2008), or the effect of the European integration (Coeurdacier et al. 2009). In this literature, taxes have only appeared as a control variable on the distribution and growth of CBAs without addressing international tax issues. The only exceptions are Huizinga and Voget (2009) who, for a sample of European countries, have related taxes with the headquarter decisions when firms merge across national borders as well as Huizinga et al. (2012) who have found that international taxation affects the takeover premia of CBAs.

FDI and CBAs do not overlap perfectly since a multinational enterprise could also undertake greenfield investment. The early theoretical and empirical literature on FDI referred primarily to greenfield investment where foreign plants are built from scratch rather than being acquired. However, only small changes are required to adapt the standard framework for addressing FDI to the case of CBAs (Antràs and Yeaple 2014, p. 83). Furthermore, a growing theoretical literature has started to look specifically at FDI through the lens of international mergers and acquisitions. This implies that FDI can be seen as an outcome of international market for corporate control, to use the title of Head and Ries (2008), where multinational enterprises engage in a bidding contest when they want to take control over foreign assets. From an empirical perspective, this provides the bridge to the location choice framework applied below, insofar as profits (and hence the bidding capacities) differ across potential host countries due to, e.g., differences in corporate taxes. In this regard, our empirical strategy follows the approach of Hijzen et al. (2008) and Coeurdacier et al. (2009).

\subsection{Determinants of FDI strategies}

Research on domestic and international mergers and acquisitions has been developing across several sub-fields such as industrial organisation, finance, and international economics. Consequently, a large number of motivations for acquisitions have been identified: synergies, competition effects, technology transfers, spreading risks by means of diversification and so on. UNCTAD (2000) gives an overview of the wider considerations that may apply to CBAs and how the impact of CBAs in the host country may differ from greenfield investment. As regards corporate taxes, CBAs also raise additional issues associated with transfer pricing and corporate inversions. Notwithstanding these observations, in this paper, we focus more directly on the different forms of CBAs which ties with the difference between horizontal and vertical strategies that dominates in the international economics literature and research on FDI in general (see Antràs and Yeaple 2014 for a recent survey).

Multinational firms pursuing a horizontal strategy seek to access markets by replicating production facilities overseas, whilst a vertical strategy encapsulates the desire 
to fragment the production process. Vertical FDI involves the fragmentation of the supply chain, with the production abroad leading to the export of intermediate goods. Reflecting the different motives, horizontal and vertical FDI have been mostly associated with investment flows between, respectively, developed and developing countries. However, the dominance of horizontal FDI between developed countries has been questioned by Alfaro and Charlton (2009) who show-by directly measuring the vertical relatedness between affiliate activity and the parent company-that a substantial part of FDI between developed countries is actually vertical in nature with a large proportion of this being intra-industry (that is, within broad industry aggregates). ${ }^{4}$

Following the discussion above, it is relatively straightforward to apply the various FDI strategies to the case of CBAs (Antràs and Yeaple 2014, pp. 83ff.). In particular, a horizontal motive would imply that a foreign acquisitions involves a target firm in the same industry to gain market access considerations, whilst a vertical motive would imply that a foreign acquisition involves a target firm on a different stage of the value chain to out-source production stages.

\subsection{The role of taxes}

There is a substantial body of research measuring the responsiveness of FDI to corporate taxes. Early studies drew on statutory rates. Though the corresponding data are readily available for a large number of countries, the rates stipulated in the tax code are not necessarily appropriate when it comes to the market entry decisions that manifest in the acquisition of a foreign firm. To more appropriately capture the long-term implications of a foreign market entry that arise with FDI-e.g. taking into account the capital depreciation and tax allowances of such investments - the effective average tax rate (EATR) measures the net present value of tax payments as a proportion of the net present value of pre-tax capital income (see Devereux and Griffith 1998; Devereux et al. 2002; Buettner and Ruf 2007). Related to the EATR is the effective marginal tax rate (EMTR) which measures the proportionate difference in post- and pre-tax rates of return. This should matter more for incremental investments in foreign firms rather than the location choices that occur when taking over control by means of a CBA.

The burden of corporate taxation will also depend on the tax system applied with respect to credits on taxes paid abroad, the treatment of repatriated profits, or the withholding taxes imposed in the host country. An early study considering such international tax issues is Blonigen and Davies (2004), who found little evidence that the existence of a bilateral tax treaty had an effect on US inbound and outbound FDI. Within the context of CBAs, Huizinga and Voget (2009) provide a more comprehensive view in terms of compiling data reflecting the contents of specific tax treaties. They found that differences between countries applying a worldwide (or credit based) and a territorial (or exemption based) tax system and the role of withholding tax rates agreed in tax treaties impact upon the parent firm location in a given country. Without

\footnotetext{
4 The determination of the FDI strategies outlined in Sect. 3, follows Alfaro and Charlton (2009).
} 
focusing on CBAs, but using a similar approach to Huizinga and Voget (2009), Barrios et al. (2012) suggest that source and host country taxes affect the location decision of establishing foreign subsidiaries. ${ }^{5}$ It is important to note that the methodology we apply follows Barrios et al. (2012) by relating to the discrete location decisions of MNEs. However, as discussed in Sect. 5, our econometric strategy can cope with the location choices embodied in the enormous number of CBA deals around the world.

Whilst the literature on FDI has primarily considered the role of corporate taxes, according to Desai et al. (2004) and Buettner and Wamser (2009), other (indirect) taxes may also matter. This hypothesis rests on the observation that in most countries the indirect tax burden levied on sales or labour cost of firms can exceed the amounts to be paid in direct corporate income tax. However, as far as we are aware, the effect of, for example, sales and labour taxes on CBAs has not yet been established. Desai et al. (2004) argue that, whilst the international tax system deals with the role of credits to avoid double corporate taxation, indirect taxes have no credit system that applies. This, however, is only partially true when it comes to sales taxes: for FDI that is motivated by market access (horizontal FDI), it is indeed the case that sales taxes will apply and cannot be credited. But FDI can also be motivated by the fragmentation of supply chains and foreign subsidiaries producing intermediate goods that are usually exported back to the parent country (or some other country). As sales taxes can usually be refunded at the border, they can be trade neutral (Keen and Syed 2006). ${ }^{6}$

As regards corporate taxation, the differences between greenfield investment and mergers and acquisitions have appeared in Becker and Fuest (2010, 2011). However, these theoretical contributions are mainly concerned with the welfare effects of tax competition and coordination across different international tax systems. The only paper that has explicitly addressed the crucial distinction between horizontal and vertical integration is by Mutti and Grubert (2004). In particular, they conjecture that corporate taxes will have no effect on horizontal FDI, since the corresponding affiliates will be on the same footing as domestic firms in the host country. Conversely, high taxes on vertical FDI will place a subsidiary at a disadvantage, since it will be competing with firms in the source country that have not invested abroad. The effect of taxes may therefore depend on the motivation for FDI. However, apart from the lack of account for the role of double taxation and international tax relief, Mutti and Grubert (2004) also have no direct measure of vertical FDI. Still, the main merit of the their paper is to tie with the focus of the international economics literature that MNEs pursue different strategies and that this might matter for the effect of taxation.

In sum, it is clear from the preceding discussion that different taxes can have a differential impact on the investment decisions of firms to invest in a foreign country. But establishing the exact effect of those taxes on CBAs necessitates a method that identifies FDI strategies, together with a careful consideration of double tax issues. It is the former issue that we next turn to.

\footnotetext{
5 Whilst the focus here is on tax elasticities, as we note throughout, there may be many issues associated with taxes and CBAs. As one of the referees pointed out, the role tax-havens may be a relevant. However, there is no country in our sample that appears on the OECD tax-haven list.

6 Desai and Hines (2005) find the VAT to have a negative effect on net exports though they put this down to inefficiencies in the VAT rebate system across the panel of countries they cover.
} 


\section{Horizontal and vertical CBAs}

Driven by the availability of detailed tax data, we focus on international CBAs between 32 source and 31 host countries. ${ }^{7}$ During the $1999-2010$ period, according to SDC Platinum of Thomson Reuters, these countries have witnessed 82,182 deals and accounted for more than $90 \%$ of the total number CBAs around the world. SDC Platinum has been used elsewhere for empirical research on CBAs. Early studies (among others, Rossi and Volpin 2004 and Giovanni 2005) have relied on the aggregate value of the reported deals between pairs of source and host countries. The caveat against this is that in the majority of cases, the deal value has not been disclosed by the merging firms (Giovanni 2005, p. 134). To avoid this missing data problem, the literature (see, for instance, Herger et al. 2008; Hijzen et al. 2008; Huizinga and Voget 2009, and Erel et al. 2012) has relied on the number of deals, which is almost exhaustively available, since SDC records virtually any change in ownership of at least $5 \%{ }^{8}$

To disentangle the impact of taxation across FDI strategies, the challenge is to distinguish between horizontal and vertical CBAs. For each deal, SDC Platinum reports standard industry classification (SIC) codes of the acquirer and foreign target firm at the 4-digit level denoted here by, respectively, $\operatorname{SIC}_{a}$ and $\mathrm{SIC}_{b} .{ }^{9}$ This provides the basis to uncover the industrial relationship between the merging firms. In particular, when $\mathrm{SIC}_{a}=\mathrm{SIC}_{b}$, an acquisition involves firms operating in the same industry, which is a typical feature of horizontal integration.

When tying down vertical acquisitions, however, it is not sufficient to observe that the SIC codes of the acquiring and target firms differ; one also needs a direct measure of vertical relatedness that will explicitly identify the links within the supply chain. Therefore, we draw on the methodology of Fan and Lang (2000) and Fan and Goyal (2006), who have derived a measures of vertical relatedness from the input: output structure of commodity flows between around 500 intermediate industries using US accounts. More specifically, for every pair of industries, $\mathrm{SIC}_{a}$ and $\mathrm{SIC}_{b}$, the input: output tables allow the calculation of the value of sales from $\mathrm{SIC}_{a}$ required to produce a dollar's worth of $\mathrm{SIC}_{b}$. The higher this measure-called the vertical relatedness coefficient and denoted by $V_{a b}$-the greater the degree to which the corresponding industries are linked through the supply chain. By defining a benchmark $\bar{V}$, it is then possible to identify deals between firms operating in industries with $V_{a b}>\bar{V}$ that are deemed to be vertically related. Following Alfaro and Charlton (2009), the $5 \%$ benchmark for $\bar{V}$ will be used for the baseline results, whilst the 1 and $10 \%$ values will be used for robustness checks.

\footnotetext{
7 The list of countries can be found in the data appendix.

8 Results between count and value data can, of course, differ since they refer, respectively, to the effect of taxes on the location choice of a multinational firm and the amount to invest, once the decision to enter a foreign market has been taken. Econometric issues arising with event counts are discussed in Sect. 5.

9 To accurately identify investment strategies pursued by multinational firms, Alfaro and Charlton (2009) strongly advocate the use of a highly disaggregated classification at the four-digit level. Arguably, this avoids the misclassification of a considerable number of acquisitions involving firms in adjacent industries as horizontal acquisitions.
} 
Table 1 Definition of horizontal and vertical FDI

\begin{tabular}{lll}
\hline FDI strategy & Horizontal relatedness & Vertical relatedness \\
\hline Pure horizontal & $\exists r, s$ such that $\operatorname{SIC}_{a}^{r}=\operatorname{SIC}_{b}^{s}$ & $V_{a b}^{r s}<\bar{V}, \forall r, s$ \\
Pure vertical & $\operatorname{SIC}_{a}^{r} \neq \mathrm{SIC}_{b}^{s}, \forall r, s$ & $\exists$ r,s such that $V_{a b}^{r s}>\bar{V}$ \\
\hline
\end{tabular}

One potential issue in matching SIC codes is that firms often operate in several industries; the SDC database reports up to 6 different SIC codes for both acquiring and target firms. To reflect the prevalence of diversified multinational firms, we analyse the horizontal and vertical relatedness between an acquirer, denoted by $r$, and target firm, denoted by $s$, across every potential pair of industries in which they operate. Since there are up to six industries for acquiring and a target firm there are up to 36 pairs which imply the following classification: as to whether CBAs involve firms that are horizontally, that is $\operatorname{SIC}_{a}^{r}=\operatorname{SIC}_{b}^{s}$, or vertically, that is $V_{a b}^{r s}>\bar{V}$, related:

(i.) 'Pure horizontal' acquisitions between acquiring and target firms sharing at least one combination of 4-digit SIC codes, but are vertically unrelated in any of the 36 possible combinations of $\mathrm{SIC}_{a}^{r}$ and $\mathrm{SIC}_{b}^{s}$; and

(ii.) 'Pure vertical' acquisitions between acquiring and target firms related in at least one combination of industries through the supply chain, but have no common industry codes for across the (up to) 36 combinations of $\mathrm{SIC}_{a}^{r}$ and $\mathrm{SIC}_{b}^{s}$ codes.

Table 1 formalises the definition of the alternative FDI strategies. ${ }^{10}$

The distribution of the 82,182 CBAs between 1999 and 2010 in the sample of source and host countries is reported in Table 2. The second column shows the breakdown of all deals across the top 10 source and host countries. Notice that the same developed countries, that is the USA, the UK, Canada, Germany, and France, are the most important source and host nations for CBAs and that they alone account already for more than half of all deals.

Using the methodology of Table 1, the alternative investment strategies characterising these CBAs are reported in the remaining columns of Table 2. Of the total number of acquisitions, around $50 \%$ of all deals are classified as purely horizontal or vertical. Using the $5 \%$ benchmark for $\bar{V}, 19 \%$ are classified as 'pure' horizontal and $37 \%$ as 'pure' vertical. Substantial shifts in the distribution of FDI strategies arise when alternative benchmarks are used for $\bar{V}$. Specifically, with the $10 \%$ benchmark employed (which raises the threshold of vertical relatedness defining that industries are connected through the supply chain), around $29 \%$ are classified as 'pure' horizontal and $11 \%$ as 'pure' vertical acquisitions. Conversely, with the $1 \%$ benchmark employed (which lowers the threshold for defining vertical integration), vertical deals dominate with $57 \%$ whilst only $8 \%$ of all CBAs would be deemed to be horizontal.

\footnotetext{
10 Notice that the classification can also produce less clear outcomes. For example, acquisitions involving firms in the same SIC also pass the measure of vertical relatedness. This would be compatible with complex strategies combining several motives for FDI as discussed in, for example, Yeaple (2003). However, to avoid ambiguities and produce a close concurrence with the established theories on FDI strategies, the analysis will focus on acquisitions that are 'purely' horizontal or vertical according to the definition of Table 1.
} 
Table 2 Number of CBAs, 1999-2010

\begin{tabular}{|c|c|c|c|}
\hline & AllC BAs & $\begin{array}{l}\text { Horizontal } \\
(\bar{V}=5 \%)\end{array}$ & $\begin{array}{l}\text { Vertical } \\
(\bar{V}=5 \%)\end{array}$ \\
\hline \multicolumn{4}{|c|}{ Top 10 source countries } \\
\hline USA & 20,064 & 3113 & 6130 \\
\hline UK & 10,892 & 2275 & 2916 \\
\hline Canada & 7248 & 1226 & 2514 \\
\hline Germany & 5927 & 1089 & 1811 \\
\hline France & 5698 & 1507 & 1608 \\
\hline Netherlands & 3777 & 796 & 1111 \\
\hline Sweden & 3216 & 754 & 870 \\
\hline Switzerland & 2992 & 602 & 864 \\
\hline Australia & 2832 & 480 & 814 \\
\hline Japan & 2654 & 330 & 939 \\
\hline Total & 82,182 & 15,671 & 24,250 \\
\hline \multicolumn{4}{|c|}{ Top 10 host countries } \\
\hline USA & 16,440 & 3159 & 5136 \\
\hline UK & 9320 & 1832 & 2864 \\
\hline Germany & 7159 & 1293 & 2107 \\
\hline Canada & 5815 & 970 & 1657 \\
\hline France & 4921 & 931 & 1387 \\
\hline Spain & 3096 & 770 & 756 \\
\hline Australia & 3052 & 413 & 881 \\
\hline Sweden & 2921 & 601 & 867 \\
\hline Italy & 2871 & 613 & 762 \\
\hline Netherlands & 2727 & 494 & 838 \\
\hline Total & 82,182 & 15,671 & 24,250 \\
\hline
\end{tabular}

Hence, a shift between the conventionally used benchmark values $\bar{V}$ has a substantial effect on the empirical distribution between horizontal and vertical strategies meaning that it will be important to make this distinction when establishing the effect of taxes on CBAs below.

\section{Double taxation and international tax relief}

Aside from the distinction between statutory and effective tax rates discussed in Sect. 2, international tax matters - and, in particular, double taxation and international tax relief-influence investment decisions. Following Huizinga and Voget (2009) and Barrios et al. (2012), the consolidated tax burden, denoted by $\tau_{i j t}$, from FDI between source country $i$ into host country $j$ during year $t$ is given by

$$
\tau_{i j t}=\tau_{j t}+\tau_{i t}+\left(1-\tau_{j t}\right) \omega_{i j t},
$$

where $\tau_{j t}$ is the host country tax rate, $\tau_{i t}$ is the source country $i$ tax rate, and $\omega_{i j t}$ captures any withholding taxes when multinationals repatriate the after-tax profits, given 
by $\left(1-\tau_{j t}\right)$, to the source country $i$. Since most FDI is subject to some double tax relief, the tax rate in (1) is rarely applied in practice. The amount of double tax relief depends on the international tax system - that is, whether the source country applies a territorial or worldwide regime where international tax relief occurs, respectively, through exemptions and tax credits - and whether the source and host country have signed a bilateral tax treaty stipulating the tax system that applies between them or the maximum amount of withholding taxes. In countries with a territorial tax system, foreign profits are exempted from domestic taxation implying that $\tau_{i t}=0$. The international tax burden on the multinationals is, then,

$$
\tau_{i j t}^{e}=\tau_{j t}+\left(1-\tau_{j t}\right) \omega_{i j t}
$$

In countries with a worldwide system, domestic corporate taxes must be paid even if the profits have been earned abroad but, to reduce the double tax burden, firms can earn credits on foreign tax payments. ${ }^{11}$ The international tax burden on the multinationals is, then,

$$
\tau_{i j t}=\tau_{i t}+\tau_{j t}+\left(1-\tau_{j t}\right) \omega_{i j t}-c_{i j t}
$$

where $c_{i j t}$ denotes the tax credits.

With an indirect tax credit system corporate and withholding taxes are both creditable, that is $c_{i j t}^{i}=\tau_{j t}+\left(1-\tau_{j t}\right) \omega_{i j t}$, whereas direct tax credits apply only to withholding taxes meaning $c_{i j t}^{d}=\left(1-\tau_{j t}\right) \omega_{i j t}$. Since the tax credit is restricted to the tax burden that would accrue to the same profit in the parent country, we have that $c_{i j t}^{i}=\min \left[\tau_{i t}, \tau_{j t}+\left(1-\tau_{j t}\right) \omega_{i j t}\right]$ and $c_{i j t}^{d}=\min \left[\tau_{i t}, \omega_{i j t}\right]$ (Huizinga and Voget 2009, p. 1223). In sum, the international tax burden equals

$$
\tau_{i j t}^{i}= \begin{cases}\tau_{j, t}+\left(1-\tau_{j t}\right) \omega_{i j t} & \text { if } \tau_{j t}+\left(1-\tau_{j t}\right) \omega_{i j t}>\tau_{i t} \\ \tau_{i t} & \text { if } \tau_{j t}+\left(1-\tau_{j t}\right) \omega_{i j t}<\tau_{i t}\end{cases}
$$

for the indirect tax credit system and

$$
\tau_{i j t}^{d}= \begin{cases}\tau_{j t}+\left(1-\tau_{j t}^{d}\right) \omega_{i j t} & \text { if } \omega_{i j t}>\tau_{i t} \\ \tau_{j t}+\left(1+\omega_{i j t}\right) \tau_{i, t} & \text { if } \omega_{i j t}<\tau_{i t}\end{cases}
$$

for the direct tax credit system (see also Barrios et al. 2012, pp. 949ff.). ${ }^{12}$

One issue in dealing with double taxation and international tax relief is the potential to defer the repatriation of profits and, hence, postpone the payment of corporate taxes

\footnotetext{
11 During the period under consideration, a number of countries have switched from a credit based towards an exemption-based system. Examples include the Czech Republic (2004), Norway (2004), Poland (2007), Japan (2009), and the UK (2009) with the year of the transition reported in parentheses.

12 Before changing to an exemption-based system in 2004, the Czech Republic used a deduction-based system where foreign taxes can be subtracted from the domestic taxable profits. According to Barrios et al. (2012), the international tax rate is then equal to $1-\left(1-t_{i t}\right)\left(1-\tau_{j t}\right)\left(1-\omega_{i j t}\right)$.
} 
in the home country. ${ }^{13}$ In practice, it is difficult to establish whether a firm has an incentive to keep unrepatriated profits in an acquired subsidiary abroad (see Huizinga and Voget 2009, pp. 1230ff.). Furthermore, most countries impose complex rules and regulations as regards the repatriation of foreign profits. Hence, one merit of distinguishing between the effect of host country taxes $\tau_{j t}$ and the international tax burden $\tau_{i j t}$ is that this might shed light into the importance of deferral (Barrios et al. 2012, p. 951). In particular, a lower impact of $\tau_{i j t}$ compared with $\tau_{j t}$ could suggest that the repatriation of profits is often deferred to a degree where issues of double taxation are of minor concern. A possible difference with the host country tax effect can arise from both the withholding tax $\omega_{i j t}$ or the additional corporate taxes that can accrue, in particular, in parent countries with a worldwide tax system. In sum, we will use the host country tax $\tau_{j t}$, measured with the statutory or effective rates, as baseline variables as well as (2)-(5) to infer the effect of international double taxation on CBAs.

For a set of European countries, Huizinga and Voget (2009) and Barrios et al. (2012) provide detailed information about the tax system as well as the withholding tax rates that apply according to bilateral tax treaties. To calculate the international tax burden, we have compiled some new data that also cover major countries outside Europe that appear in our common sample including Argentina, Australia, Brazil, Canada, Hong Kong, Indonesia, Japan, Mexico, Singapore, the USA, and South Africa. ${ }^{14}$ To concur with Huizinga and Voget (2009) and Barrios et al. (2012), profits are assumed to be repatriated in form of dividends.

As mentioned above, non-profit taxes might also matter for the location choice of firms. To account for this, we follow the literature (Desai et al. 2004; Buettner and Wamser 2009) and include the rates of value-added and other sales taxes in the host country. Furthermore, labour taxes and the amount of compulsory social security contributions to be paid in each country might be relevant when the desire to outsource labour intensive production stages to low-wage countries provides the motive for acquiring a foreign firm. Following Braconier et al. (2005), labour tax data have been extracted from the Prices and Earnings survey of UBS (various years). ${ }^{15}$

\section{A location choice framework for CBAs}

CBAs encapsulate a decision to locate economic activities in a given host country. Therefore, the analysis of this data is conducted within a location choice framework,

\footnotetext{
13 Another issue is that effective tax rates are usually calculated for local conditions, whilst in an international context, the tax burden on an investment depends also on the conditions abroad. This could give rise to non-linearities between, say, withholding and effective corporate taxes. As in Huizinga and Voget (2009) and Barrios et al. (2012), these complex second order effects are neglected here. Recent data accounting for this are only available for a set of European countries (see ZEW 2008).

14 The sources to compile this information were the Corporate and Indirect Tax Survey of KPMG (various years), the Deloitte International Tax Source (DITS), the country-specific lists of double taxation treaties of UNCTAD, as well as information published by the relevant national tax authorities.

15 Buettner and Wamser (2009) also consider the role of import duties and excises for which they find no effect on the location choice of German multinationals. Since the trade freedom variable, discussed in Sect. 5, already contains a component measuring the tariff barrier in each country, we have not included a separate variable for import duties and excises.
} 
which models the host country decision embodied in each deal. ${ }^{16}$ Specifically, the desire to acquire a foreign subsidiary rests on the opportunity to generate an income stream of $R$ and, thus, earn an expected profit of

$$
\pi_{i j t}^{d}=\left(1-\tau_{i j t}\right) R\left(x_{i j t}, \tau_{j t}^{o}, \delta_{i}, \delta_{j}, \delta_{t}\right)
$$

whose value depends, in turn, on several factors. ${ }^{17}$ In particular, as discussed above, firms are thought to be reluctant to invest in the face of high tax rates $\tau_{i j t}$ levied directly on corporate income, but also other forms of taxation $\tau_{j t}^{o}$ accruing, for example, to the value-added component of $R$. The control variables are summarised in $x_{i j t}$. Yearspecific components $\delta_{t}$ absorb global developments within the international market for corporate control that sustain the observed wave-like pattern in international merger activity (see Giovanni 2005). Finally, $\delta_{i}$ and $\delta_{j}$ absorb all factors that are specific to, respectively, the source and host countries.

Equation (6) forms the basis for our empirical strategy. However, expected profits $\pi_{i j t}$ are not directly observable. Therefore, we follow a growing literature (see, for example, Devereux and Griffith 1998; Buettner and Ruf 2007; Buettner and Wamser 2009; Barrios et al. 2012, and Head and Ries 2008) exploiting the fact that observed CBA deals encapsulate a location choice that identifies the country with the highest expected profit opportunity, that is

$$
h_{i j t}^{d}= \begin{cases}1 & \pi_{i j t}^{d}>\pi_{i j^{\prime} t}^{d} \\ 0 & \text { otherwise, }\end{cases}
$$

where $j^{\prime}$ denotes alternative hosts where a firm could, in principle, also have made an acquisition. Insofar as taxes affect the profits according to (8), they determine the desirability of multinational firms to bid for foreign firms in various host countries and manifest themselves finally in the market entry decision of $h_{i j t}^{d}$.

The regression equation related with (6) is given by

$$
\begin{gathered}
\pi_{i j t}^{d}=\tilde{x}_{j t} \beta+\tilde{\tau}_{i j t} \gamma+\delta_{i}+\delta_{j}+\delta_{t}+\epsilon_{i j t}, \\
i=1, \ldots, I ; j=1, \ldots, J ; t=1, \ldots, T
\end{gathered}
$$

where $\tilde{x}_{i j t}=\ln \left(x_{i j t}\right)$ and $\tilde{\tau}_{i j t}=\ln \left(\tau_{i j t}\right)$, and $\beta$ and $\gamma$ are coefficients to be estimated, and $\epsilon_{i j t}$ is a deal-specific error term.

Aside from the details of the tax variables $\tilde{\tau}_{i j t}$ that have been discussed in the previous section, the set of control variables $\tilde{x}_{i j t}$ accounts for the established factors

\footnotetext{
16 This paper, therefore, departs from the bulk of the empirical literature which measures the impact of taxes upon aggregate stocks and flows of FDI by means of gravity equations. Though similar variables are employed, it is important to emphasise that the specification of location choice models differs from the standard gravity equations. Above all, location choice models are highly non-linear since they draw on extreme value distributions identifying the best option available. Therefore, the handling of country and time-specific effects differs fundamentally from linear gravity equations.

17 See Devereux and Griffith (1998) for a similar specifications to modelling the profits of multinationals.
} 
to explain the location choices of multinational firms. In particular, real GDP in the host country reflects the market access motive of FDI. The expected sign is positive since it is more likely that a multinational firm acquires a target in a larger economy. Higher wage costs are expected to have a negative effect on the decision to locate in any specific country. Owing to the separate inclusion of labour taxes, a measure for wages net of payroll taxes and compulsory social security contributions is used. Even when wages are low, multinational firms might be reluctant to enter foreign markets with rigid labour market regulations. This is proxied by an index on labour market freedom. The distance between the source and host countries as well as whether they share a common border account for the effect of geography on FDI. Trade freedom is an index that captures the absence of tariff and non-tariff barriers to trade in the host country. For the multinational firm, this will matter when intermediate goods provide inputs for foreign subsidiaries or given that exports (subject to trade costs) can be used as an alternative strategy to establishing a local plant when serving a foreign market.

Other factors which influence the openness of the country to FDI are given by investment freedom, an index measuring whether the government treats foreign firms in the same way as domestic investors, whether specific industries are closed to investment, whether governments impose restrictions on capital transactions and transfers- the expected effect of this variable is positive. An index on shareholder rights controls for the role of corporate governance, emphasised in Rossi and Volpin (2004), when acquiring a foreign firm. During the period under consideration, a number of countries joined the European Union or adopted the Euro as a common currency. Following Coeurdacier et al. (2009), this will be captured by two sets of dummy variables reflecting, respectively, whether source and host country or only the host country are a member of the European Union or the Euro. Finally, exchange rates are also a likely determinant of FDI. Following Froot and Stein (1991) and Blonigen (1997), a (real) appreciation of the currency of the host country is expected to have a negative effect since this makes a foreign acquisition more expensive when expressed in the home currency. Detailed definitions and data sources as well as the summary statistics for each of the variables are reported in the data appendix.

Head and Ries (2008) have developed a framework to theoretically model the bidding process that occurs when FDI is thought to arise via the international market for corporate control. One of the main ingredients of their approach is that the dealspecific component error term $\epsilon_{i j t}$ is assumed to follow a Gumbel, or type I extreme value distribution, to reflect that the highest bid is going to win in a stylised auction for the control of a foreign target. From this, it is a short step to see that the probability that a firm of source country $i$ acquires a target in country $j$ during year $t$ takes a multinomial logit form, that is

$$
P_{i j t}^{d}=P_{i j t}=\frac{\exp \left(\tilde{x}_{i j t} \beta+\tilde{\tau}_{i j t} \gamma+\delta_{j}\right)}{\sum_{i=1}^{I} \sum_{l=1}^{M} \sum_{t=1}^{T} \exp \left(\tilde{x}_{i l t} \beta+\tilde{\tau}_{i l t} \gamma+\delta_{j}\right)} .
$$

Owing to the exponential nature of (9), the components $\delta_{i}$ and $\delta_{t}$ pertaining, respectively, to source countries and years drop out. Thus, only variables such as taxes that differ across the alternatives, that is the host countries $j$, affect the location choice 
embodied in each CBA deal. In other words, location choice approaches obviously exploit the heterogeneity in, say taxes, arising between the locations a multinational firm can potentially choose from. ${ }^{18}$

Though models of the (binary, conditional, and nested) have been used to estimate how corporate taxes impact upon location choices such as $h_{i j t}^{d}$ (see, for example, Devereux and Griffith 1998; Buettner and Ruf 2007; Buettner and Wamser 2009; Barrios et al. 2012), their main limitation is the massive number of observations in a sample encompassing a large number of countries and years as we have here. For example, our sample with $82,182 \mathrm{CBA}$ deals and 31 potential host countries would have necessitated the compilation of a dataset with around 2,500,000 observations. However, the issue that location choice models of the logit class can become very cumbersome to estimate can be avoided by turning to the Poisson regression (Guimarães et al. 2003), which has the advantage of requiring a substantially smaller number of observation to obtain the same coefficients (see also; Schmidheiny and Brülhart 2011; Herger and McCorriston 2013). ${ }^{19}$ In this case, the interpretation of the coefficients, such as $\gamma$, pertaining to logarithmically transformed coefficients, such as $\tau_{j t}$, is that of a constant (tax) elasticity. "Appendix 3" provides the technical details.

The present location choice framework for CBAs has benefits in that it is embedded in the profit function (6) that can, in turn, be connected with theoretical models of FDI and CBAs. However, there are also some limitations. Firstly, the choice is here over the acquisition of a foreign subsidiary and, in the version above, does not contemplate other dimensions such as the difference between mergers and acquisitions and greenfield investment (Becker and Fuest 2011) or the choice of headquarter (Huizinga and Voget 2009). Also, firm-specific considerations such of profit shifting and tax planning drop out with the deal-specific component $\delta_{d}$. Nevertheless, tax effects on location choices by means of CBAs are an important part of international tax competition and the current framework provides a comprehensive and tractable method to estimate the corresponding effects. The next section will turn to the results.

\section{Results}

\subsection{Baseline results}

Table 3 reports the results connecting the econometric approaches that are based on the location choice revealed from CBA deals with the empirical literature on FDI and taxes. Ignoring for the moment additional parent country and withholding taxes, Columns 1 and 2 employ statutory tax rates, Columns 3 and 4 effective average tax rates, and Columns 5 and 6 effective marginal tax rates to measure $\tau_{j t}$. Columns 2,4 ,

\footnotetext{
18 One should be aware of the deviations from conventional gravity equations. Owing to the non-linear nature, even with time-dummy variables $\delta_{t}$, a time-constant variable can enter the location choice model as long as its values differ across the different options (here host countries $j$ ).

19 For a smaller sample with location choices by US multinationals, the exact overlap of the estimated tax effects between the conditional logit model and the Poisson regression is shown in Herger et al. (2011).
} 
Table 3 Results for statutory and effective tax rates

\begin{tabular}{|c|c|c|c|c|c|c|}
\hline \multirow[t]{2}{*}{ Corporate tax } & \multicolumn{2}{|c|}{ Statutory rate } & \multicolumn{2}{|l|}{ EATR } & \multicolumn{2}{|l|}{ EMTR } \\
\hline & (1) & (2) & (3) & (4) & (5) & (6) \\
\hline GDP & $\begin{array}{l}0.49 * * * \\
(0.11)\end{array}$ & $\begin{array}{l}0.48^{* * * *} \\
(0.11)\end{array}$ & $\begin{array}{l}0.43^{* * * *} \\
(0.11)\end{array}$ & $\begin{array}{l}0.42^{* * *} \\
(0.11)\end{array}$ & $\begin{array}{l}0.39 * * * \\
(0.11)\end{array}$ & $\begin{array}{l}0.38 * * * \\
(0.11)\end{array}$ \\
\hline Net wage & $\begin{array}{l}0.01 \\
(0.03)\end{array}$ & $\begin{array}{l}0.01 \\
(0.03)\end{array}$ & $\begin{array}{l}0.01 \\
(0.03)\end{array}$ & $\begin{array}{l}0.01 \\
(0.03)\end{array}$ & $\begin{array}{l}0.01 \\
(0.03)\end{array}$ & $\begin{array}{l}0.01 \\
(0.03)\end{array}$ \\
\hline Distance & $\begin{array}{l}-0.62^{* * * *} \\
(0.01)\end{array}$ & $\begin{array}{l}-0.62 * * * \\
(0.01)\end{array}$ & $\begin{array}{l}-0.62 * * * \\
(0.01)\end{array}$ & $\begin{array}{l}-0.62 * * * \\
(0.01)\end{array}$ & $\begin{array}{l}-0.62 * * * \\
(0.01)\end{array}$ & $\begin{array}{l}-0.62 * * * \\
(0.01)\end{array}$ \\
\hline Border & $\begin{array}{l}0.47 * * * \\
(0.01)\end{array}$ & $\begin{array}{l}0.47 * * * \\
(0.01)\end{array}$ & $\begin{array}{l}0.47 * * * \\
(0.01)\end{array}$ & $\begin{array}{l}0.47 * * * \\
(0.01)\end{array}$ & $\begin{array}{l}0.47 * * * \\
(0.01)\end{array}$ & $\begin{array}{l}0.47 * * * \\
(0.01)\end{array}$ \\
\hline Investment freedom & $\begin{array}{l}0.20 * * * \\
(0.04)\end{array}$ & $\begin{array}{l}0.18^{* * * *} \\
(0.04)\end{array}$ & $\begin{array}{l}0.19 * * * \\
(0.04)\end{array}$ & $\begin{array}{l}0.17 * * * \\
(0.04)\end{array}$ & $\begin{array}{l}0.19 * * * \\
(0.04)\end{array}$ & $\begin{array}{l}0.16^{* * *} \\
(0.04)\end{array}$ \\
\hline Trade freedom & $\begin{array}{l}-0.04 \\
(0.07)\end{array}$ & $\begin{array}{l}-0.04 \\
(0.08)\end{array}$ & $\begin{array}{l}-0.05 \\
(0.07)\end{array}$ & $\begin{array}{l}-0.04 \\
(0.08)\end{array}$ & $\begin{array}{l}-0.05 \\
(0.07)\end{array}$ & $\begin{array}{l}-0.05 \\
(0.08)\end{array}$ \\
\hline $\begin{array}{l}\text { Labour market } \\
\text { freedom }\end{array}$ & $\begin{array}{l}0.40^{* * * *} \\
(0.13)\end{array}$ & $\begin{array}{l}0.33^{* * * *} \\
(0.13)\end{array}$ & $\begin{array}{l}0.36^{* * * *} \\
(0.12)\end{array}$ & $\begin{array}{l}0.30 * * \\
(0.13)\end{array}$ & $\begin{array}{l}0.30 * * \\
(0.12)\end{array}$ & $\begin{array}{l}0.24 * \\
(0.12)\end{array}$ \\
\hline Shareholder rights & $\begin{array}{l}1.47 * * * \\
(0.16)\end{array}$ & $\begin{array}{l}1.45^{* * * *} \\
(0.16)\end{array}$ & $\begin{array}{l}1.43^{* * * *} \\
(0.16)\end{array}$ & $\begin{array}{l}1.42^{* * *} \\
(0.16)\end{array}$ & $\begin{array}{l}1.37 * * * \\
(0.16)\end{array}$ & $\begin{array}{l}1.36^{* * * *} \\
(0.16)\end{array}$ \\
\hline $\mathrm{EU}_{i t}^{*} \mathrm{EU}_{j t}$ & $\begin{array}{l}-0.51 \\
(0.57)\end{array}$ & $\begin{array}{l}-0.50 \\
(0.57)\end{array}$ & $\begin{array}{l}-0.51 \\
(0.57)\end{array}$ & $\begin{array}{l}-0.50 \\
(0.57)\end{array}$ & $\begin{array}{l}-0.50 \\
(0.57)\end{array}$ & $\begin{array}{l}-0.49 \\
(0.57)\end{array}$ \\
\hline$\left(1-\mathrm{EU}_{i t}\right)^{*} \mathrm{EU}_{j t}$ & $\begin{array}{l}-0.01 \\
(0.57)\end{array}$ & $\begin{array}{l}0.001 \\
(0.57)\end{array}$ & $\begin{array}{l}-0.01 \\
(0.57)\end{array}$ & $\begin{array}{l}0.001 \\
(0.57)\end{array}$ & $\begin{array}{l}0.004 \\
(0.57)\end{array}$ & $\begin{array}{l}0.01 \\
(0.57)\end{array}$ \\
\hline Euro $_{i t}^{*}$ Euro $_{j t}$ & $\begin{array}{l}0.27 * * * \\
(0.06)\end{array}$ & $\begin{array}{l}0.26^{* * * *} \\
(0.06)\end{array}$ & $\begin{array}{l}0.26 * * * \\
(0.06)\end{array}$ & $\begin{array}{l}0.26^{* * * *} \\
(0.06)\end{array}$ & $\begin{array}{l}0.26 * * * \\
(0.06)\end{array}$ & $\begin{array}{l}0.26^{* * * *} \\
(0.06)\end{array}$ \\
\hline$\left(1-\text { Euro }_{i t}\right)^{*}$ Euro $_{j t}$ & $\begin{array}{l}-0.38 * * * \\
(0.06)\end{array}$ & $\begin{array}{l}-0.38 * * * \\
(0.06)\end{array}$ & $\begin{array}{l}-0.38 * * * \\
(0.06)\end{array}$ & $\begin{array}{l}-0.39 * * * \\
(0.06)\end{array}$ & $\begin{array}{l}-0.39 * * * \\
(0.06)\end{array}$ & $\begin{array}{l}-0.39 * * * \\
(0.06)\end{array}$ \\
\hline Exchange rate & $\begin{array}{l}-0.54^{* * * *} \\
(0.05)\end{array}$ & $\begin{array}{l}-0.54 * * * \\
(0.05)\end{array}$ & $\begin{array}{l}-0.56^{* * *} \\
(0.05)\end{array}$ & $\begin{array}{l}-0.56^{* * * *} \\
(0.05)\end{array}$ & $\begin{array}{l}-0.58^{* * *} \\
(0.05)\end{array}$ & $\begin{array}{l}-0.58 * * * \\
(0.05)\end{array}$ \\
\hline $\begin{array}{l}\text { Corporate tax }\left(\tau_{j t}\right) \\
\text { (host country) }\end{array}$ & $\begin{array}{l}-0.21 * * * \\
(0.06)\end{array}$ & $\begin{array}{l}-0.22 * * * \\
(0.06)\end{array}$ & $\begin{array}{l}-0.17 * * * \\
(0.06)\end{array}$ & $\begin{array}{l}-0.17 * * * \\
(0.06)\end{array}$ & $\begin{array}{l}-0.04 \\
(0.03)\end{array}$ & $\begin{array}{l}-0.04 \\
(0.03)\end{array}$ \\
\hline Sales tax & & $\begin{array}{l}-0.19 * * * \\
(0.07)\end{array}$ & & $\begin{array}{l}-0.15^{* *} \\
(0.07)\end{array}$ & & $\begin{array}{l}-0.15^{* * *} \\
(0.07)\end{array}$ \\
\hline Labour tax & & $\begin{array}{l}0.06 \\
(0.05)\end{array}$ & & $\begin{array}{l}0.07 \\
(0.05)\end{array}$ & & $\begin{array}{l}0.07 \\
(0.05)\end{array}$ \\
\hline \# CBA & 82,182 & 82,182 & 82,182 & 82,182 & 82,182 & 82,182 \\
\hline \# Obs & 11,248 & 11,248 & 11,248 & 11,248 & 11,248 & 11,248 \\
\hline $\ln L$ & $-26,079$ & $-26,075$ & $-26,081$ & $-26,079$ & $-26,085$ & $-26,082$ \\
\hline
\end{tabular}

The dependent variable is the number $n_{i j t}$ of CBA deals between source country $i$ and host country $j$ during year $t$. Estimation is by maximum likelihood of a Poisson regression with fixed effects $\alpha_{i t}$. Aside from the dummy variables (Border, EU, Euro), the explanatory variables have been transformed into logarithms such that the coefficients reflect constant elasticities. All specification include host country dummy variables $\delta_{j}$. For the 1999-2010 period, the data cover all CBAs between the 32 source and 31 host countries listed in the data appendix. Furthermore, \# CBA is the total number of deals, \# obs is the number of observations, and $\ln L$ the maximised value of the log-likelihood function of the Poisson regression. Standard errors (SE), clustered by $\alpha_{i t}$, are reported in parentheses.

* Significant at the $10 \%$ level; ** Significant at the $5 \%$ level; *** Significant at the $1 \%$ level 
and 6 consider this with the inclusion of other taxes levied on sales and wage payments. The results refer to the number of CBAs during the 1999-2010 period with 82,182 observed deals between 32 source and 31 host countries for which detailed tax data were available (see data appendix). The sample involves an unbalanced panel with 11,248 observations covering 379 pairs of source countries and years. ${ }^{20}$

Inspection of the results across the six specifications of Table 3 reveals that the coefficients of the control variables concur with the theoretical priors. In particular, economic size, a cheap foreign currency, the proximity between countries, institutional quality (in terms of investment and labour market freedom and the protection of shareholder rights), and joint membership of the Euro Zone significantly enhance a country's capacity to attract CBAs. EU membership and trade freedom have an insignificant effect, which might reflect that the trade barriers within our sample with mainly developed host countries are already relatively low. The effect of wage cost is also insignificant. Again, within the current sample with mainly developed countries, the desire to outsource labour intensive production processes to low-wage countries is apparently not a key factor driving international acquisitions. Note, however, that the variable that measures labour market flexibility is significant.

With respect to taxation, as noted above, there is broad evidence that corporate taxes reduce a country's capacity to attract FDI. This is confirmed by the results of Table 3 , where corporate taxes $\tau_{j t}$, measured by statutory and effective average rates in Columns 1-4, have a negative and significant effect on CBA activity. With the EMTR, an insignificant coefficient arises in Columns 5 and 6. This is perhaps not surprising since effective marginal tax rates should matter for incremental investments affecting the value of FDI rather than the discrete location choices associated with the number of CBAs. ${ }^{21}$ Interestingly, compared with the vast literature on the effect of taxes on FDI, the values of the elasticities are relatively low.

Other dimensions of taxation matter for international investment decisions. For the sample covering all CBAs, relatively high sales taxes reduce the probability that a foreign country attracts an acquisition. This coincides with the findings of Desai et al. (2004) about the effect of indirect taxes on the affiliate sales of US multinationals, but differs from Buettner and Wamser (2009), who found that sales taxes had no significant effect on the location choice by German multinationals. Taxes levied on wage payments have no significant effect on the location choices inferred from CBA deals. This result coincides with that of Buettner and Wamser (2009), who attributed

\footnotetext{
20 As noted in Sect. 5 and shown in "Appendix 3", the coefficient estimates that resulted from a fixed effects Poisson regression are identical with those of a conditional logit model for the location choice of host countries $j$.

21 We have also experimented with some regressions using the deal value of CBAs as the dependent variable. Recall, from the discussion of Sect. 3, that these data are highly incomplete in the sense that for the majority of CBAs, SDC Platinum did not report the deal value. Furthermore, a preponderance of the aggregate deal values between source and host countries during a given year were zero-valued. This issue could be tackled with either a Tobit regression or a pseudo Poisson maximum likelihood approach. In both cases, when using aggregate deal values, a significant effect did arise with the EMTR. However, as mentioned above, the incompleteness of the value data introduce severe caveats. Therefore, we do not report and discuss these results here.
} 
this to a scenario where labour is inelastically supplied, and internationally immobile, and as such they bear the labour tax burden.

\subsection{International tax effects}

Table 4 extends the analysis of the impact of taxes upon CBAs by accounting additional parent country and withholding taxes. As discussed in Sect. 4, multinational firms can be subject to double taxation. Specifically, Columns 1 and 2 of Table 4 consider the effect the international corporate tax burden $\tau_{i j t}$ that depends, according to Eqs. (2)(5), on such things as the international tax system, the double tax relief stipulated in bilateral tax treaties, or the withholding tax rate $\omega_{i j t}$ when repatriating profits from host country $j$ to parent country $i$.

Similar to the results above, international corporate taxes impact negatively upon the number of CBAs regardless whether they are measured on the basis of statutory or effective average rates in, respectively, Column 1 and $2 .{ }^{22}$ Recall that the international tax burden applies only when profits are repatriated, which is notoriously difficulty to verify. Hence, the differences between the results of Tables 3 and 4 could provide some indirect evidence on the relevance of deferring the repatriation of profits in order to reduce the tax burden. In this regard, for CBAs, there is no evidence that the deferral reduces the importance of the (international) tax burden on corporate profits. Rather, with coefficients of around -0.4 , the impact of the international tax burden $\tau_{i j t}$ is more than double the corresponding value of the host country tax $\tau_{j t}$ used in Table 3. Barrios et al. (2012, p. 953) found an even larger elasticity of around -0.8 on the international corporate tax burden. However, their sample covered only 909 new foreign subsidiaries within European countries, whilst our data cover more than 80,000 CBAs from countries around the world.

The remaining columns of Table 4, following Barrios et al. (2012), split the international corporate tax burden $\tau_{i j t}$ into its individual components. Distinguishing again between statutory and effective average rates, together with corporate taxes in the host country $\tau_{j t}$, Columns 3 and 4 introduce a separate variable for the double tax burden $\tau_{i j t}-\tau_{j t}$ arising when profits are repatriated to a given parent country. The effect is again negative. As discussed in Sect. 4, the additional taxes a multinational firm has to pay depend mainly on the tax system of the parent country and the withholding tax rates in the country from which the profits are repatriated. Columns 5 and 6 distinguish these components by attributing double taxes to the effect of withholding taxes $\left(1-\tau_{j t}\right) \omega_{i j t}$ and the corporate taxes remaining to be paid in the parent country $\tau_{i j t}-\tau_{j t}-\left(1-\tau_{j t}\right) \omega_{i j t}$. Note that the latter can vary across locations since the parent country tax rate depends, for example, on whether a bilateral income tax treaty has been signed with a given host country. A significantly negative effect arises for the additional taxes in the parent country, which is consistent with the findings [but not the magnitude of the coefficients of the corporate tax components: the ones being smaller

\footnotetext{
22 We have not calculated the international tax burden with the EMTR, since the withholding taxes, which enters the international tax burden, accrues to the after-tax profits that are repatriated. Meanwhile, the EMTR measures the difference in post- and pre-tax rates of return, which is somewhat disconnected with the actual tax payments that define the value of, for example, tax credits.
} 
Table 4 Results with the international tax burden

\begin{tabular}{|c|c|c|c|c|c|c|}
\hline Corporate tax & $\begin{array}{l}\text { Statutory } \\
\text { (1) }\end{array}$ & $\begin{array}{l}\text { EATR } \\
\text { (2) }\end{array}$ & $\begin{array}{l}\text { Statutory } \\
\text { (3) }\end{array}$ & $\begin{array}{l}\text { EATR } \\
\text { (4) }\end{array}$ & $\begin{array}{l}\text { Statutory } \\
\text { (5) }\end{array}$ & $\begin{array}{l}\text { EATR } \\
(6)\end{array}$ \\
\hline GDP & $\begin{array}{l}0.48 * * * \\
(0.11)\end{array}$ & $\begin{array}{l}0.44 * * * \\
(0.11)\end{array}$ & $\begin{array}{l}0.34 * * * \\
(0.11)\end{array}$ & $\begin{array}{l}0.33 * * * \\
(0.11)\end{array}$ & $\begin{array}{l}0.28 * * * \\
(0.12)\end{array}$ & $\begin{array}{l}0.27 * * * \\
(0.11)\end{array}$ \\
\hline Net wage & $\begin{array}{l}0.02 \\
(0.03)\end{array}$ & $\begin{array}{l}0.02 \\
(0.03)\end{array}$ & $\begin{array}{l}0.01 \\
(0.03)\end{array}$ & $\begin{array}{l}0.01 \\
(0.03)\end{array}$ & $\begin{array}{l}-0.003 \\
(0.03)\end{array}$ & $\begin{array}{l}-0.01 \\
(0.03)\end{array}$ \\
\hline Distance & $\begin{array}{l}-0.61 * * * \\
(0.01)\end{array}$ & $\begin{array}{l}-0.61^{* * * *} \\
(0.01)\end{array}$ & $\begin{array}{l}-0.58^{* * * *} \\
(0.01)\end{array}$ & $\begin{array}{l}-0.61 * * * \\
(0.01)\end{array}$ & $\begin{array}{l}-0.58^{* * * *} \\
(0.01)\end{array}$ & $\begin{array}{l}-0.61 * * * \\
(0.01)\end{array}$ \\
\hline Border & $\begin{array}{l}0.49 * * * \\
(0.01)\end{array}$ & $\begin{array}{l}0.49 * * * \\
(0.01)\end{array}$ & $\begin{array}{l}0.49 * * * \\
(0.02)\end{array}$ & $\begin{array}{l}0.50 * * * \\
(0.01)\end{array}$ & $\begin{array}{l}0.49 * * * \\
(0.02)\end{array}$ & $\begin{array}{l}0.49 * * * \\
(0.01)\end{array}$ \\
\hline Investment freedom & $\begin{array}{l}0.16^{* * * *} \\
(0.04)\end{array}$ & $\begin{array}{l}0.16 * * * \\
(0.04)\end{array}$ & $\begin{array}{l}0.15^{* * *} \\
(0.04)\end{array}$ & $\begin{array}{l}0.15^{* * * *} \\
(0.04)\end{array}$ & $\begin{array}{l}0.11 * * * \\
(0.04)\end{array}$ & $\begin{array}{l}0.12 * * * \\
(0.04)\end{array}$ \\
\hline Trade freedom & $\begin{array}{l}-0.03 \\
(0.08)\end{array}$ & $\begin{array}{l}-0.04 \\
(0.08)\end{array}$ & $\begin{array}{l}-0.01 \\
(0.08)\end{array}$ & $\begin{array}{l}-0.04 \\
(0.08)\end{array}$ & $\begin{array}{l}-0.01 \\
(0.08)\end{array}$ & $\begin{array}{l}-0.05 \\
(0.08)\end{array}$ \\
\hline $\begin{array}{l}\text { Labour market } \\
\text { freedom }\end{array}$ & $\begin{array}{l}0.35 * * * \\
(0.13)\end{array}$ & $\begin{array}{l}0.35 * * * \\
(0.13)\end{array}$ & $\begin{array}{l}0.22 * \\
(0.13)\end{array}$ & $\begin{array}{l}0.29 * * \\
(0.13)\end{array}$ & $\begin{array}{l}0.20 \\
(0.13)\end{array}$ & $\begin{array}{l}0.29 * * \\
(0.13)\end{array}$ \\
\hline Shareholder rights & $\begin{array}{l}1.40 * * * \\
(0.16)\end{array}$ & $\begin{array}{l}1.36 * * * \\
(0.16)\end{array}$ & $\begin{array}{l}1.26^{* * *} \\
(0.17)\end{array}$ & $\begin{array}{l}1.19 * * * \\
(0.16)\end{array}$ & $\begin{array}{l}1.12^{* * *} \\
(0.17)\end{array}$ & $\begin{array}{l}1.04 * * * \\
(0.16)\end{array}$ \\
\hline $\mathrm{EU}_{i t}^{*} \mathrm{EU}_{j t}$ & $\begin{array}{l}-0.52 \\
(0.57)\end{array}$ & $\begin{array}{l}-0.54 \\
(0.57)\end{array}$ & $\begin{array}{l}-0.50 \\
(0.58)\end{array}$ & $\begin{array}{l}-0.60 \\
(0.57)\end{array}$ & $\begin{array}{l}-0.54 \\
(0.58)\end{array}$ & $\begin{array}{l}-0.65 \\
(0.57)\end{array}$ \\
\hline$\left(1-\mathrm{EU}_{i t}\right)^{*} \mathrm{EU}_{j t}$ & $\begin{array}{l}0.01 \\
(0.57)\end{array}$ & $\begin{array}{l}-0.02 \\
(0.57)\end{array}$ & $\begin{array}{l}0.05 \\
(0.58)\end{array}$ & $\begin{array}{l}-0.04 \\
(0.57)\end{array}$ & $\begin{array}{l}0.01 \\
(0.58)\end{array}$ & $\begin{array}{l}-0.10 \\
(0.57)\end{array}$ \\
\hline Euro $_{i t}^{*}$ Euro $_{j t}$ & $\begin{array}{l}0.27 * * \\
(0.06)\end{array}$ & $\begin{array}{l}0.27 * * \\
(0.06)\end{array}$ & $\begin{array}{l}0.28 * * * \\
(0.06)\end{array}$ & $\begin{array}{l}0.26 * * * \\
(0.06)\end{array}$ & $\begin{array}{l}0.28 * * * \\
(0.06)\end{array}$ & $\begin{array}{l}0.25 * * * \\
(0.06)\end{array}$ \\
\hline$\left(1-\text { Euro }_{i t}\right)^{*}$ Euro $_{j t}$ & $\begin{array}{l}-0.36^{* * * *} \\
(0.06)\end{array}$ & $\begin{array}{l}-0.36^{* * * *} \\
(0.06)\end{array}$ & $\begin{array}{l}-0.35^{* * * *} \\
(0.06)\end{array}$ & $\begin{array}{l}-0.32^{* * * *} \\
(0.06)\end{array}$ & $\begin{array}{l}-0.31^{* * * *} \\
(0.06)\end{array}$ & $\begin{array}{l}-0.28 * * * \\
(0.06)\end{array}$ \\
\hline Exchange rate & $\begin{array}{l}-0.50 * * * \\
(0.05)\end{array}$ & $\begin{array}{l}-0.53 * * * \\
(0.05)\end{array}$ & $\begin{array}{l}-0.51 * * * \\
(0.05)\end{array}$ & $\begin{array}{l}-0.57 * * * \\
(0.05)\end{array}$ & $\begin{array}{l}-0.55^{* * *} \\
(0.05)\end{array}$ & $\begin{array}{l}-0.62 * * * \\
(0.05)\end{array}$ \\
\hline $\begin{array}{l}\text { Corporate tax } \\
\text { (international: } \\
\tau_{i j t} \text { ) }\end{array}$ & $\begin{array}{l}-0.40 * * * \\
(0.03)\end{array}$ & $\begin{array}{l}-0.41^{* * * *} \\
(0.03)\end{array}$ & & & & \\
\hline $\begin{array}{l}\text { Corporate tax } \\
\left.\text { (host: } \tau_{j t}\right)\end{array}$ & & & $\begin{array}{l}-0.27 * * * \\
(0.06)\end{array}$ & $\begin{array}{l}-0.28 * * * \\
(0.06)\end{array}$ & $\begin{array}{l}-0.24 * * * \\
(0.06)\end{array}$ & $\begin{array}{l}-0.23 * * * \\
(0.06)\end{array}$ \\
\hline $\begin{array}{l}\text { Corporate tax } \\
\quad\left(\text { double: } \tau_{i j t}-\tau_{j t}\right)\end{array}$ & & & $\begin{array}{l}-0.12^{* * * *} \\
(0.01)\end{array}$ & $\begin{array}{l}-0.14^{* * * *} \\
(0.01)\end{array}$ & & \\
\hline $\begin{array}{l}\text { Corporate tax } \\
\text { (parent: } \tau_{i j t}- \\
\left.\tau_{j t}-\left(1-\tau_{j t}\right) \omega_{i j t}\right)\end{array}$ & & & & & $\begin{array}{l}-0.09^{* * * *} \\
(0.01)\end{array}$ & $\begin{array}{l}-0.06^{* * *} \\
(0.01)\end{array}$ \\
\hline $\begin{array}{l}\text { Withholding tax } \\
\quad\left(\left(1-\tau_{j t}\right) \omega_{i j t}\right)\end{array}$ & & & & & $\begin{array}{l}-0.15^{* * * *} \\
(0.01)\end{array}$ & $\begin{array}{l}-0.17 * * * \\
(0.01)\end{array}$ \\
\hline Sales tax & $\begin{array}{l}-0.19^{* * * *} \\
(0.07)\end{array}$ & $\begin{array}{l}-0.15^{* * *} \\
(0.07)\end{array}$ & $\begin{array}{l}-0.17 * * \\
(0.07)\end{array}$ & $\begin{array}{l}-0.15^{* *} \\
(0.07)\end{array}$ & $\begin{array}{l}-0.25^{* * *} \\
(0.07)\end{array}$ & $\begin{array}{l}-0.27 * * * \\
(0.07)\end{array}$ \\
\hline
\end{tabular}


Table 4 continued

\begin{tabular}{lllllll}
\hline Corporate tax & $\begin{array}{l}\text { Statutory } \\
(1)\end{array}$ & $\begin{array}{l}\text { EATR } \\
(2)\end{array}$ & $\begin{array}{l}\text { Statutory } \\
(3)\end{array}$ & $\begin{array}{l}\text { EATR } \\
(4)\end{array}$ & $\begin{array}{l}\text { Statutory } \\
(5)\end{array}$ & $\begin{array}{l}\text { EATR } \\
(6)\end{array}$ \\
\hline Labour tax & 0.07 & 0.08 & 0.06 & 0.06 & 0.01 & 0.01 \\
& $(0.05)$ & $(0.05)$ & $(0.06)$ & $(0.05)$ & $(0.06)$ & $(0.05)$ \\
\# CBA & 82,182 & 82,182 & 82,182 & 82,182 & 82,182 & 82,182 \\
\# Obs & 11,248 & 11,248 & 11,248 & 11,248 & 11,248 & 11,248 \\
$\ln L$ & $-25,979$ & $-26,013$ & $-23,717$ & $-25,838$ & $-23,628$ & $-25,786$ \\
\hline
\end{tabular}

The dependent variable is the number $n_{i j t}$ of CBA deals between source country $i$ and host country $j$ during year $t$. Estimation is by maximum likelihood of a Poisson regression with fixed effects $\alpha_{i t}$. Aside from the dummy variables (Border, EU, Euro), the explanatory variables have been transformed into logarithms such that the coefficients reflect constant elasticities. All specifications include host country dummy variables $\delta_{j}$. For the 1999-2010 period, the data cover all CBAs between the 32 source and 31 host countries listed in the data appendix. Furthermore, \# CBA is the total number of deals, \# obs is the number of observations, and $\ln L$ the maximised value of the log-likelihood function of the Poisson regression. SE, clustered by $\alpha_{i t}$, are reported in parantheses.

* Significant at the $10 \%$ level; ** Significant at the $5 \%$ level; *** Significant at the $1 \%$ level

than in the aggregate cases of Columns (1) and (2)] of Barrios et al. (2012, pp. 954, 956). The effect of withholding taxes is also significantly negative. The corresponding effect in Barrios et al. (2012) is insignificant which is perhaps not surprising since their sample contained only European countries where withholding taxes tend to be low and, for EU countries, even zero by virtue of the EU Parent-Subsidiary Directive.

\subsection{Horizontal and vertical CBAs}

Following the procedure outlined in Sect. 3, Table 5 reports the results that relate to the distinction between the horizontal (Columns 1-4) and vertical (in Columns 5-8) strategies for FDI using the $5 \%$ benchmark for $\bar{V}$ to identify deals that are deemed vertically related. Recall that the sample contains only deals where a 'purely' horizontal or vertical relationship between acquiring and target firms could be identified. The results have been calculated with statutory and effective average corporate tax rates. Furthermore, to account for the role of double taxation, a distinction is made between corporate taxes measured by the host country rate (as in Table 3 ) and the international rate (as in Columns 1 and 2 of Table 4$){ }^{23}$

Some intuitive differences arise with respect to the impact of the control variables when CBAs are driven by different FDI strategies. ${ }^{24}$ In particular, as expected, GDP has

\footnotetext{
23 The detailed decomposition of the international tax effects on horizontal and vertical acquisitions along the lines reported in Table 4 is presented in a summary table below.

24 To test whether horizontal and vertical deals give rise to different models, the fact that they are strictly non-nested needs taking into account. For this scenario, the likelihood ratio statistic $L R=$ $(1 / \sqrt{n}) \sum_{i=1}^{n} \ln \left[l\left(C B A_{i}^{\mathrm{hor}} \mid x_{i j t}, \tau_{i j t}, \beta^{\text {hor }}, \gamma^{\text {hor }}\right) / l\left(C B A_{i}^{\text {ver }} \mid x_{i j t}, \tau_{i j t}, \beta^{\text {ver }}, \gamma^{\text {ver }}\right)\right] / \widehat{\omega}^{2}$, where $n$ is the number of observations and $\widehat{\omega}^{2}=(1 / n) \sum_{i=1}^{n} \ln \left[l\left(\mathrm{CBA}_{i}^{\text {hor }} \mid x_{i j t}, \tau_{i j t}, \beta^{\text {hor }}, \gamma^{\text {hor }}\right) / l\left(C B A_{i}^{\text {ver }} \mid x_{i j t}, \tau_{i j t}\right.\right.$, $\left.\left.\beta^{\text {ver }}, \gamma^{\text {ver }}\right)\right]^{2}$, converges to a standard normal distribution (Cameron and Trivedi 1998, p. 184). For all pairs of horizontal and vertical location choice models in Table 5, the value of the corresponding test statistic
} 
only a significant effect on horizontal CBAs, since they reflect the desire to access, preferably, large markets. Trade freedom has a negative effect on horizontal CBAs (though this is only significant at the $10 \%$ level), which is maybe not surprising since it is relatively more attractive to serve a market via exports, rather than local production, the lower the trade barriers. Though the host countries encompass developed countries, a substantial fraction of CBAs in our sample seems to be driven by vertical strategies (see also Table 2). This is consistent with the findings of Alfaro and Charlton (2009), who suggested that a class of what they call high-skill intra-industry vertical strategies arises between countries that are similar in terms of, for example, wage cost. Against this background, the distinction between horizontal and vertical acquisition strategies does not give rise to large differences as regards the effect of wage costs. ${ }^{25}$ Still, labour market matter for separating the motives for horizontal and vertical acquisitions, but this effect is captured through labour market flexibility, which has a significant effect on vertical, but not horizontal CBAs.

With respect to the hypothesis of Mutti and Grubert (2004), for our comprehensive sample of CBAs, there is some evidence that the effect of corporate taxes is greater on multinational firms pursuing vertical strategy of multinational integration. The tax elasticities are in general more negative for vertical FDI. Furthermore, similar to the result of Table 4, for both horizontal and vertical FDI, corporate taxes matter more when additional parent country and withholding tax issues are taken into account. In particular, when measuring taxes with the host country rate (in the odd columns), the effect is insignificant. Again, there is no evidence that the possibility to defer the repatriation of profits lowers the impact of the international tax burden for horizontal or vertical FDI.

With respect to indirect taxes, labour taxes are insignificant for both forms of acquisitions. However, a striking difference that arises in Table 5 is that sales taxes do have a negative and highly significant impact on horizontal FDI, whilst the corresponding coefficient is lower, and insignificant, for vertical acquisitions. This result, which has to our knowledge not been observed before, is intuitive since exported goods are often exempted from local sales taxes and the primary rationale for vertical integration relates exactly to the production of intermediate inputs to downstream stages of the supply chain located in other countries. Conversely, with horizontal acquisitions, multinational firms integrate a foreign plant to produce and sell goods locally such that the sales tax should matter, which is confirmed with the results produced here.

\footnotetext{
Footnote 24 continued

is slightly higher than 5 , which suggests that the models pertaining to horizontal and vertical deals differ statistically in a highly significant manner.

25 The outsourcing of labour intensive production stages to low-wage countries arises probably mainly with emerging markets for which panel data on, e.g. the EATR are not available. However, for the year 2004, some cross-sectional tax data for a larger set of host countries appears in Djankov et al. (2010). Based on this, we have experimented with a cross section of 43 host countries including large emerging markets such as Brazil, China, India, South Africa, Thailand, or Turkey. With this, a differential effect does arise in terms wage costs having a significant impact on vertical, but not on horizontal FDI. Furthermore, similar to the findings below, sales taxes enter with a negative sign for horizontal, but not for vertical FDI.
} 


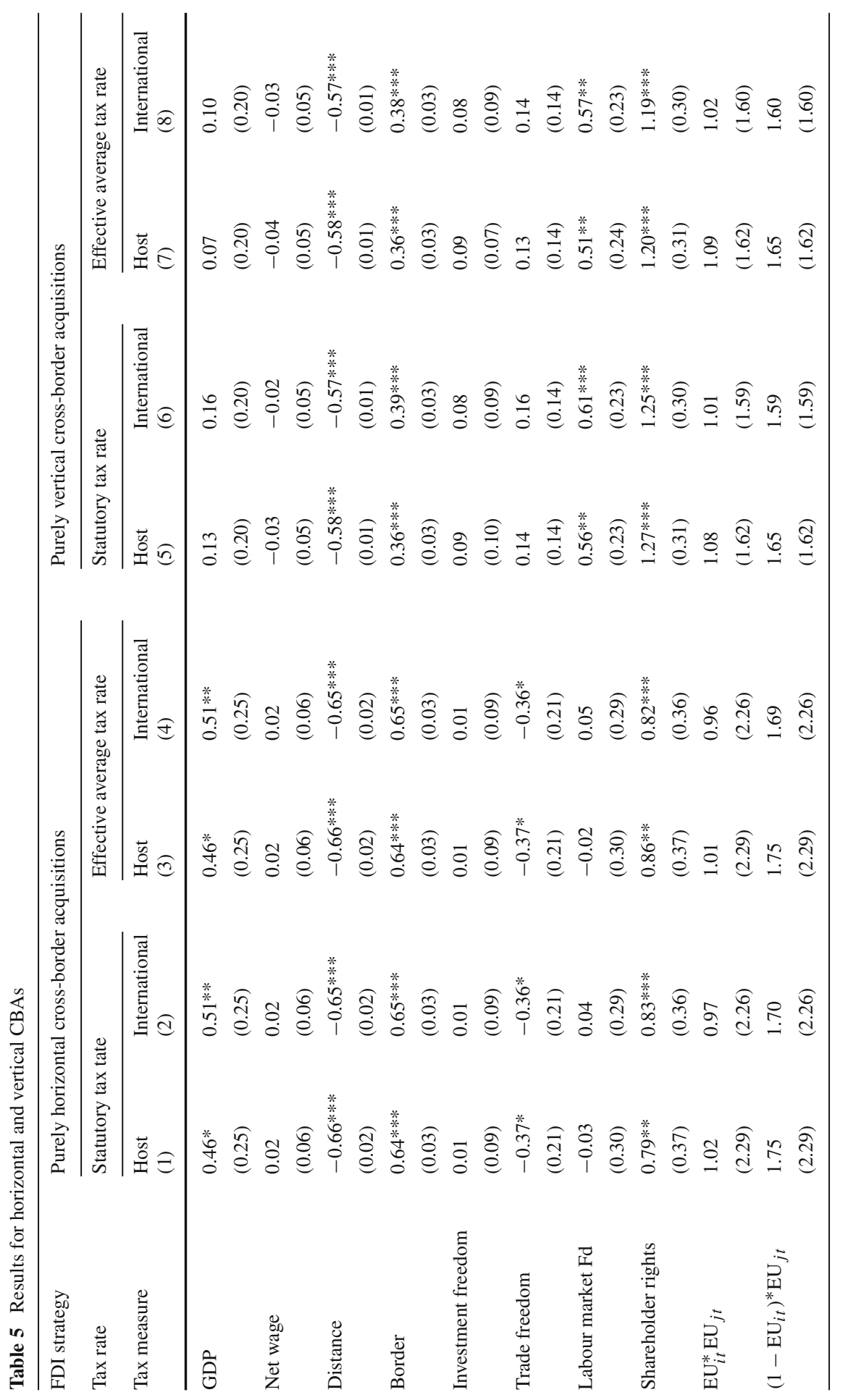




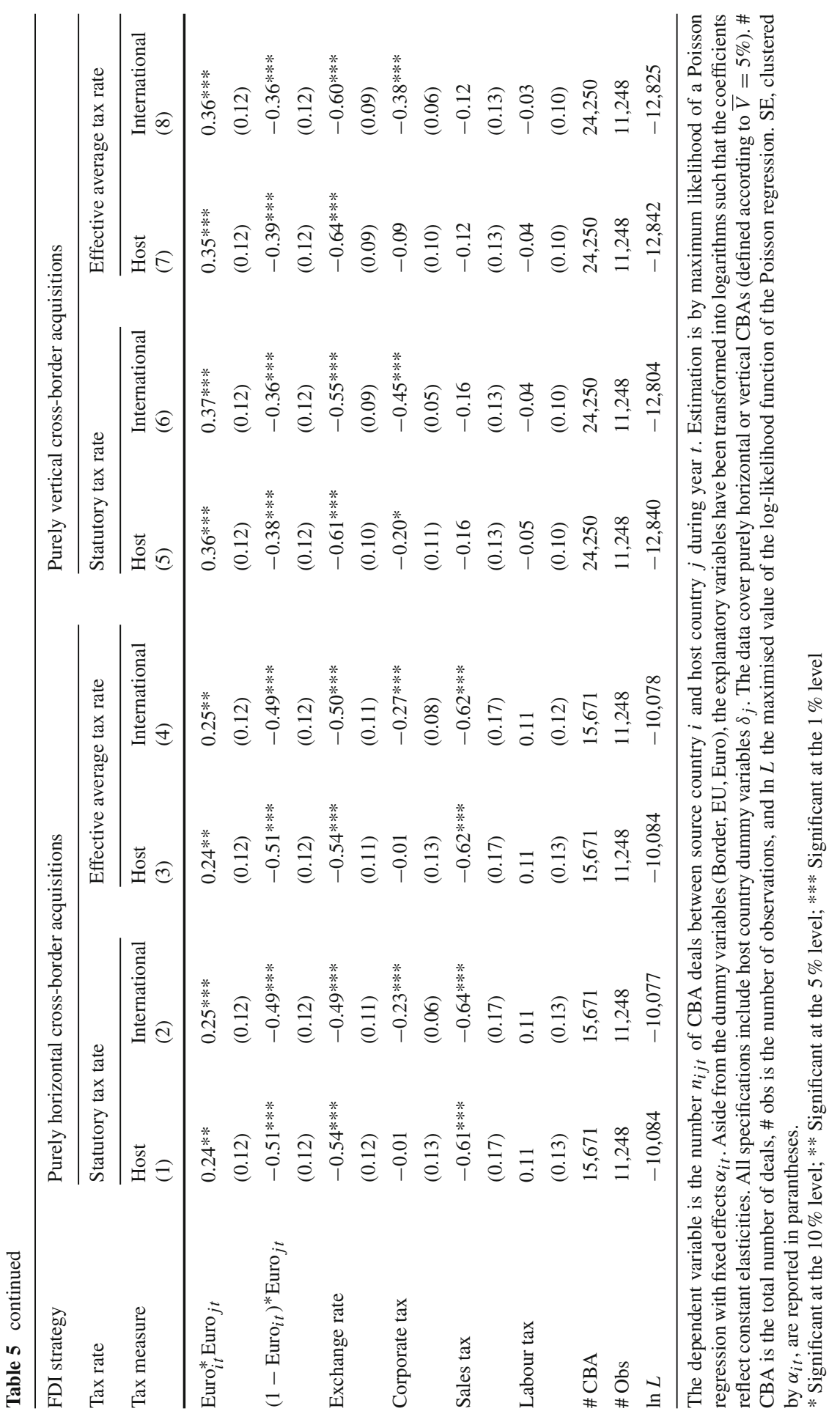




\subsection{Robustness checks}

The results reported above are robust to a number of changes in variable definitions and, in the case of distinguishing between horizontal and vertical acquisitions, to changes in the vertical-relatedness benchmark.

Controlling for the role of institutional quality in FDI is a thorny issue. A broad range of often highly correlated variables encompassing such things as the protection of property rights, the pervasiveness of corruption, regulatory efficiency, or the openness of a country to foreign business have been found to affect FDI (see, for example, Daude and Stein 2007). To comprehensively account for the plethora of institutional quality variables, we have also recalculated the results with a composite index of economic freedom, which summarises variables pertaining to the rule of law, government efficiency, regulatory efficiency, and open markets. However, this did not change the essence of our tax results.

Note from the discussion of Sect. 5 that all our results have been calculated with fixed effects $\alpha_{i t}$ that absorb any variable that does not differ across host countries. ${ }^{26}$ Among many other things, this accounts for trade freedom in the source country, which could inhibit vertical acquisitions involving exports from the host country back to the source country. Aside of producing a connection with the location choice model, the specification of the fixed effect with $\alpha_{i t}$ has also the advantage of eliminating the issue as to whether the explanatory variables need transforming into logarithmic differences. For taxes, both the levels (Buettner and Ruf 2007) and differences (Huizinga and Voget 2009) have been used. However, since the fixed effect $\alpha_{i t}$ absorbs all source and year-specific heterogeneity, the same coefficient estimates arise when the tax burden is expresses in (log) levels of a host country or the corresponding (log) difference between source and host country.

Our data also cover some of the years, during which the global economy witnessed the extraordinary events of the global financial crisis. Though it is still too early to assess whether this has lead to structural shifts in the international market for corporate control, we have calculated our results for the period 1999 to 2007 only. Again, this did not affect the main conclusions above.

A key feature in terms of highlighting the differences across alternative forms of CBAs is the characterisation of horizontal and vertical acquisitions. In the results reported in Table 5, the $5 \%$ value was used for $\bar{V}$ to define vertical relatedness. Changing the vertical relatedness benchmark reallocates the proportion of CBAs between the horizontal and vertical strategies (see Sect. 3). The results with the alternative values for $\bar{V}$ are reported in Tables 7a, b (see Electronic supplementary material). Table 7a (see Electronic supplementary material) relates to an increase of $\bar{V}$ to $10 \%$. This makes the definition of vertical acquisitions more stringent to pass and increases the number of CBA deals that are classified as horizontal. In terms of the underlying determinants, market size continues to be a determinant of horizontal, but not vertical acquisitions. The tax elasticities (relating to the international tax measure) are significant for both forms of acquisitions but are now approximately equal. However,

\footnotetext{
${ }^{26}$ The dummy variables $\delta$ further account for any specific variable shifting the intercept of the host country.
} 
Table 6 Overview of tax elasticities

\begin{tabular}{|c|c|c|c|}
\hline & All CBAs & Horizontal CBAs & Vertical CBAs \\
\hline \multicolumn{4}{|c|}{ Corporate tax measured by statutory rate } \\
\hline International tax & -0.40 & -0.23 & -0.45 \\
\hline Host country tax & -0.21 to -0.27 & -0.01 & -0.20 \\
\hline Source country tax & -0.09 & & \\
\hline Withholding tax & -0.15 & & \\
\hline \multicolumn{4}{|c|}{ Corporate tax measured by EATR } \\
\hline International tax & -0.41 & -0.27 & -0.38 \\
\hline Host country tax & -0.17 to -0.28 & -0.01 & -0.09 \\
\hline Source country tax & -0.06 & & \\
\hline Withholding tax & -0.17 & & \\
\hline \multicolumn{4}{|l|}{ Sales tax } \\
\hline Sales tax & -0.15 to -0.27 & -0.61 to -0.64 & -0.12 to -0.16 \\
\hline \multicolumn{4}{|c|}{$\begin{array}{l}\text { This table provides an overview of the measured tax elasticities according to (12) across the results reported } \\
\text { in Tables } 3,4 \text { and } 5 \text {. For all contingencies, the maximum and minimum value is reported. Insignificant } \\
\text { coefficients are marked by italic letters }\end{array}$} \\
\hline \multicolumn{4}{|c|}{$\begin{array}{l}\text { of particular note is that the sales tax still acts as a negative deterrent of horizontal } \\
\text { acquisitions but has a weaker effect on vertical acquisitions, the negative effect being } \\
\text { statistically significant at the } 10 \% \text { level only. The results with the } 1 \% \text { value for } \bar{V} \text { are } \\
\text { reported in Table } 7 \mathrm{~b} \text { (see Electronic supplementary material). With this benchmark, } \\
\text { deals that are deemed to be vertical dominate and the delineation between the alter- } \\
\text { native forms becomes less clear. In terms of the corporate tax elasticities, they are } \\
\text { higher with vertical acquisitions compared with the horizontal sample. The difference } \\
\text { in sales taxes still appears but is now only significant at the } 10 \% \text { level for the horizontal } \\
\text { acquisitions, but remains insignificant for vertical acquisitions. Finally, the difference } \\
\text { between horizontal and vertical FDI pertains perhaps more to the manufacturing sec- } \\
\text { tor, where production processes can be replicated locally or our-sourced, rather than } \\
\text { services. However, recalculating Table } 5 \text { for the manufacturing sector only did not } \\
\text { change the essence of the results. }\end{array}$} \\
\hline
\end{tabular}

\subsection{Summary of tax elasticities}

Distinguishing between the different tax measures and FDI strategies, Table 6 provides an overview of the elasticities pertaining to the impact of corporate income and sales taxes. In the cases where several estimates appear across the different specifications of Tables 3, 4 and 5, the range with the highest and lowest values of the results is reported. A relatively consistent picture arises where the corporate tax elasticity on FDI is around $-2 / 5$ when profits are repatriated. This effect can be disentangled into a host country tax effect with an elasticity of around $-1 / 4$ as well as the effect of additional taxes to be paid in the source (or parent) country as well as withholding taxes which impact upon CBAs with an elasticity of less than $-1 / 10$ and around $-1 / 6$, respectively. Across FDI strategies, the effect of corporate taxes is higher for vertical 
CBAs. Finally, the sales tax elasticity is around $-1 / 5$ with substantially higher effects of up to $-2 / 3$ for FDI driven by a horizontal strategy, whilst the effect is insignificant and close to zero for vertical FDI.

Though our results coincide with the broadly shared view that taxes reduce the incentive of multinational firms to undertake foreign direct investment (FDI), there is substantial variation in the estimates of the corresponding tax elasticities. For example, for taxes levied directly on corporate profits, elasticities between 0 to -5 have been found (see De Mooij and Ederveen 2003, 2008 for an overview). But, as we show here, the impact of taxes depends on the characteristics of international taxation and it also varies across different forms of FDI. In addition, sales taxes impact on horizontal but not vertical FDI. Overall, the implications of the above range of tax elasticities is that changing direct and indirect taxes or amending details associated with international taxation will not only affect the overall level of FDI but impact on the composition between horizontal and vertical FDI.

\section{Summary}

Attracting FDI can be a goal for policy-makers and taxes provide an instrument to achieve this. Previous research has emphasised the role of modest direct corporate taxes to increase a country's appeal as host for FDI. For a large sample with more than 80,000 cross-border acquisitions (CBAs), between 30 major countries during 1999 to 2010 period, which reflects - to the best of our knowledge - the most comprehensive study on the effect of taxes upon host country choices encapsulated in CBA deals, the key insights that arise from this paper can be summarised as follows:

i. The effect of various forms of taxes upon the desire of multinational enterprises to acquire a target firm in a given host country is broadly negative.

ii. For corporate taxes, the elasticity lies broadly between $-1 / 20$ and $-9 / 20$ and for sales taxes around $-1 / 4$.

iii. The effect of corporate taxes depends on the exact measure of taxation, whether the role of the international tax burden is taken into account, as well as the FDI strategy pursued by the multinational enterprise. In particular, double taxationwhich arises when the same profit is also taxed in the parent country and when withholding taxes have to be paid in the host country when repatriating profitsincreases the detrimental effect of corporate taxes on FDI.

iv. For the case of sales taxes, the effect arises primarily with FDI that are driven by a horizontal strategy, implying that an affiliate is integrated into the multinational enterprise to sell to the local market. No significant effect on the sales tax could be found with vertical FDI, which involve subsidiaries producing export goods, on which the sales tax can normally be reimbursed at the border.

There are two broad policy conclusions that could be derived from our results. First, whilst confirming that taxes have a negative impact on FDI, the results suggest a more nuanced interpretation as the effects of taxes will depend not only on the details of the international tax system, but also on the nature of the FDI strategies which, in turn, depends on the factors that drive these decisions. Rather than asking about the effect of corporate taxes on multinational firms, it seems important to recognise that 
the reactions, for example within the international market for corporate control, can be rather versatile. Second, insofar as the issue of fiscal devaluation gathers pace involving greater use of value-added taxes, this may impact on FDI but will be contingent on the motivations for FDI.

The role of taxation within a globalised economy that is largely organised around multinational enterprises (MNEs) remains high on the policy agenda. Several on-going debates focus on a number of issues such as tax base erosion, international tax competition, how to deal with double taxation, transfer pricing, or headquarter inversion to reduce the corporate tax burden. Within the tax and public finance literature, there is indeed a broad consensus that taxes affect the decision of MNEs to invest in a given country. Though this study confirms this finding for a large number of cross border acquisitions, one of the key findings is that tax effects are cumbersome since firms pursue different strategies and various taxes arise. Further differences that have not been considered here are those between industries and firms that might give rise to even more heterogeneity. These, and many other issues, seem to leave ample scope for additional theoretical and empirical research on the interconnections between taxes and CBAs.

Acknowledgments The comments of two anonymous referees are acknowledged with thanks. We also thank Johannes Becker, Mick Keen, Arjan Lejour, Leonzio Rizzo, seminar participants at the IMF and the University of Ferrara and conference participants at the ZEW-Mannheim Conference on 'Taxing Multinational Firms' for comments on an earlier version of this paper. The usual disclaimer applies. Kotsogiannis also acknowledges financial support from the Spanish Ministry of Economy and Competitiveness, Research Project No. ECO2012-37572.

\section{Appendices}

Appendix 1: Country coverage and summary statistics

\section{Country coverage}

The common sample covers the following countries. Wage data of UBS (various years) refer to the cities in parentheses:

As source: Australia (Sydney), Austria (Vienna), Belgium (Brussels), Brazil (Sao Paulo), Canada (Toronto), China (Shanghai), Czech Republic (Prague), Denmark (Copenhagen), Finland (Helsinki), France (Paris), Germany (Frankfurt), Greece (Athens), Hongkong (Hong- kong), Hungary (Budapest), Indonesia (Djakarta), Ireland (Dublin), Italy (Milan), Japan (Tokyo), Mexico (Mexico City), Netherlands (Amsterdam), Norway (Oslo), Poland (Warsaw), Portugal (Lisbon), Russia (Moscow), Singapore (Singapore), Slovakia (Bratislava), South Africa (Johannesburg), Spain (Madrid), Sweden (Stockholm), Switzerland (Zurich), UK (London), USA (Washington).

The common sample covers the following host countries. Wage data of UBS (various years) refer to the cities in parentheses:

As host: Argentina (Buenos Aires), Australia (Sydney), Austria (Vienna), Belgium (Brussels), Brazil (Sao Paulo), Canada (Toronto), Chile (Santiago de Chile), Den- 
mark (Copenhagen), Finland (Helsinki), France (Paris), Germany (Frankfurt), Greece (Athens), India (Mumbai), Indonesia (Djakarta), Ireland (Dublin), Israel (Tel Aviv), Italy (Milan), Japan (Tokyo), Korea (Seoul), Mexico (Mexico City), Netherlands (Amsterdam), New Zealand (Auckland), Norway (Oslo), Portugal (Lisbon), South Africa (Johannesburg), Spain (Madrid), Sweden (Stockholm), Switzerland (Zurich), Turkey (Istanbul), UK (London), USA (Washington).

Summary statistics of the raw data

\begin{tabular}{|c|c|c|c|c|c|c|c|c|c|c|}
\hline & CBA & GDP & $\begin{array}{l}\text { Net } \\
\text { wage }\end{array}$ & Distance & Border & $\begin{array}{l}\text { Invest. } \\
\text { freed. }\end{array}$ & $\begin{array}{l}\text { Trade } \\
\text { freed. }\end{array}$ & $\begin{array}{l}\text { Labour } \\
\text { freed. }\end{array}$ & $\begin{array}{l}\text { Shareholder } \\
\text { righ. }\end{array}$ & $\mathrm{EU} * \mathrm{EU}$ \\
\hline Mean & 7.10 & $9.8 \mathrm{e}+11$ & 2.16 & 6.81 & 0.05 & 67.90 & 78.45 & 65.76 & 3.03 & 0.23 \\
\hline Std & 25.77 & $2.0 \mathrm{e}+12$ & 3.88 & 5.09 & 0.23 & 14.64 & 8.26 & 16.44 & 1.38 & 0.42 \\
\hline Min & 0 & $5.0 \mathrm{e}+10$ & 0.01 & 0.06 & 0 & 30 & 24 & 37 & 0 & 0 \\
\hline \multirow[t]{3}{*}{ Max } & 513 & $1.2 \mathrm{e}+13$ & 84.74 & 19.84 & 1 & 95 & 90 & 100 & 5 & 1 \\
\hline & \multirow[t]{2}{*}{$\begin{array}{c}(1-\mathrm{EU}) \\
* \mathrm{EU}\end{array}$} & \multirow[t]{2}{*}{$\begin{array}{l}\text { EURO }^{*} \\
\text { EURO }\end{array}$} & \multirow[t]{2}{*}{$\begin{array}{c}\text { (1-EURO) } \\
* \text { EURO }\end{array}$} & \multirow[t]{2}{*}{$\begin{array}{l}\text { Exchange } \\
\text { rate }\end{array}$} & \multicolumn{3}{|c|}{ Corporate tax } & \multirow[t]{2}{*}{$\begin{array}{l}\text { Sales } \\
\text { tax }\end{array}$} & \multirow[t]{2}{*}{$\begin{array}{l}\text { Labour } \\
\operatorname{tax}\end{array}$} & \\
\hline & & & & & Statutory & EATR & EMTR & & & \\
\hline Mean & 0.23 & 0.11 & 0.24 & 1.05 & 30.90 & 27.50 & 18.39 & 16.49 & 24.63 & \\
\hline Std & 0.42 & 0.32 & 0.43 & 0.55 & 6.72 & 5.68 & 5.42 & 5.48 & 8.062 & \\
\hline Min & 0 & 0 & 0 & 0.16 & 10 & 8.63 & 4.78 & 5 & 8 & \\
\hline Max & 1 & 1 & 1 & 4.70 & 51.56 & 43.77 & 32.44 & 25 & 46 & \\
\hline
\end{tabular}

Appendix 2: Data description and additional results

\begin{tabular}{|c|c|c|}
\hline Variable & Description & Source \\
\hline \multicolumn{3}{|c|}{ Dependent variable: } \\
\hline $\mathrm{n}_{i j t}$ & $\begin{array}{l}\text { Number of cross-border acquisition deals between the } \\
\text { source country } i \text { and host country } j \text { during year } t\end{array}$ & Compiled \\
\hline \multicolumn{3}{|l|}{ Tax variables } \\
\hline $\begin{array}{l}\text { Corporate tax } \\
\text { (statutory) }\end{array}$ & Statutory tax rate on corporate income in country $j$ & $\begin{array}{l}\text { KPMG, Corporate and } \\
\text { Indirect Tax Survey }\end{array}$ \\
\hline $\begin{array}{l}\text { Corporate tax } \\
\text { (EATR) }\end{array}$ & $\begin{array}{l}\text { Effective average tax rate (EATR) on corporate income } \\
\text { in country } j\end{array}$ & CBT Tax Database (2012) \\
\hline $\begin{array}{l}\text { Corporate tax } \\
\text { (EMTR) }\end{array}$ & $\begin{array}{l}\text { Effective marginal tax rate (EMTR) on corporate } \\
\text { income in country } j \text {. This is calculated by the } \\
\text { difference between the pre-tax and post-tax required } \\
\text { rates of return }\end{array}$ & CBT Tax Database (2012) \\
\hline Sales tax & Value-added tax (VAT) rate and other sales taxes & IMF, Tax Policy Division \\
\hline
\end{tabular}




\begin{tabular}{|c|c|}
\hline Variable & Description \\
\hline Labour tax & $\begin{array}{l}\text { Compulsory social security and income tax } \\
\text { contributions in per cent of gross salaries as published } \\
\text { in the Prices and Earnings survey of UBS. For the first } \\
\text { part of our sample, the Prices and Earnings survey is } \\
\text { only published triennially. Values of the missing years } \\
\text { have been filled with the closest observation available. } \\
\text { In particular, the values of the years } 1999 \text { and } 2001 \\
\text { employ the } 2000 \text { data, the values for the years } 2002 \\
\text { and } 2004 \text { employ the } 2003 \text { data, and the values for the } \\
\text { years } 2005 \text { and } 2007 \text { employ the } 2006 \text { data. Since } \\
2008 \text { yearly updates of the Prices and Earnings survey } \\
\text { are available }\end{array}$ \\
\hline
\end{tabular}

Withholding tax Withholding tax between countries assuming that profits are repatriated in form of dividends

Control variables:

Border
Distance

$E U_{i t} * E U_{j t}$
$\left(1-E U_{i t}\right) *$
$E U_{j t}$
$E U R O_{i t} *$
$E U R O_{j t}$
$\left(1-E U R O_{i t}\right) *$
$E U R O_{j t}$

Exchange rate

GDP

Investment freedom

Labour freedom
Common border between source and host country

Great circular between the capital city of the source and host country
Variable indicating the EU membership of the source and host country

Variable indicating the EU membership of the host (but not the source) country

Variable indicating that the source and host country share the Euro as common currency

Variable indicating the EURO membership of the host (but not the source) country

Real (bilateral) exchange rate with US\$

Real gross domestic product in US\$ with base year 2000 of the host country $j$

Index of freedom of investment referring to whether there is a foreign investment code that defines the country's investment laws and procedures; whether the government encourages foreign investment through fair and equitable treatment of investors; whether there are restrictions on access to foreign exchange; whether foreign firms are treated the same as domestic firms under the law whether the government imposes restrictions on payments, transfers, and capital transactions; and whether specific industries are closed to foreign investment

Index of labour market freedom on a scale from 10 to 90 measuring dimension such as minimum wages, regulation against layoffs, regulatory burden on hirings etc.
Source

UBS, Prices and Earnings. See also Braconier et al. (2005)

KPMG, Corporate and Indirect Tax Survey. Deloitte International Tax Source.

Compiled

Compiled

Compiled

Compiled

Compiled

Compiled

World Development Indicators

World Development Indicators

Heritage Foundation

Heritage Foundation 


\begin{tabular}{|c|c|c|}
\hline Variable & Description & Source \\
\hline Net wage & $\begin{array}{l}\text { Wage in the host country net of compulsory social } \\
\text { security contributions as published in the Prices and } \\
\text { Earnings survey of UBS. Wages are measured by an } \\
\text { index referring to the hourly income of } 13 \text { comparable } \\
\text { professions as paid in the capital city or the financial } \\
\text { centre of a country. For the first part of our sample, the } \\
\text { Prices and Earnings survey is only published } \\
\text { triennially. Values of the missing years have been } \\
\text { filled with the closest observation available. In } \\
\text { particular, the values of the years } 1999 \text { and } 2001 \\
\text { employ the } 2000 \text { data, the values for the years } 2002 \\
\text { and } 2004 \text { employ the } 2003 \text { data, and the values for the } \\
\text { years } 2005 \text { and } 2007 \text { employ the } 2006 \text { data. Since } \\
2008 \text { yearly updates of the Prices and Earnings survey } \\
\text { are available }\end{array}$ & $\begin{array}{l}\text { UBS, Prices and Earnings. } \\
\text { See also Braconier et al. } \\
(2005)\end{array}$ \\
\hline $\begin{array}{l}\text { Shareholder } \\
\text { rights }\end{array}$ & $\begin{array}{l}\text { Shareholder rights are measured by an anti-directors } \\
\text { rights index reflecting (i) the possibility of } \\
\text { shareholders to mail their proxy vote, (ii) whether } \\
\text { shareholders are required to deposit their shares prior } \\
\text { to the General Shareholders Meeting (iii) whether } \\
\text { cumulative voting is allowed (iv) an oppressed } \\
\text { minorities mechanism exists (5) whether the } \\
\text { minimum stake allowing shareholders to call for an } \\
\text { extraordinary shareholders meeting is more or less } \\
\text { than } 10 \% \text {. Higher values mean more power for } \\
\text { shareholders }\end{array}$ & La Porta et al. (1998) \\
\hline Trade freedom & $\begin{array}{l}\text { Index of freedom of international trade (tariff and } \\
\text { non-tariff barriers) on a scale from } 10 \text { to } 90\end{array}$ & Heritage Foundation \\
\hline
\end{tabular}

\section{Appendix 3: On the choice of the Poisson regression}

Econometric models that are capable to handle location choices include the conditional logit model, where $h_{i j t}^{d}$ is the dependent variable. The conditional logit models takes the joint distribution over all deals $d$, source countries $i$, host countries $j$, and the 11 years $t$ under consideration enter the log-likelihood function $\ln L_{c l}=\sum_{d=1}^{D} \sum_{i=1}^{N} \sum_{j=1}^{J} \sum_{t=1}^{T} \ln \left(P_{i j t}^{d}\right)$ with $P_{i j t}^{d}$ defined by (9). Since $P_{i j t}^{d}=P_{i j t}$, the number $n_{i j t}$ of CBAs can be factored out, that is $L_{c l}=\sum_{i=1}^{I} \sum_{j=1}^{J} \sum_{t=1}^{T} n_{i j t} P_{i j t}$. Inserting (9) yields

$$
\begin{aligned}
\ln L_{c l}= & \sum_{i=1}^{I} \sum_{j=1}^{J} \sum_{t=1}^{T} n_{i j t}\left(\widetilde{x}_{i j t} \beta+\tilde{\tau}_{i j t} \gamma+\delta_{j}\right) \\
& -\sum_{i=1}^{I} \sum_{j=1}^{J} \sum_{t=1}^{T}\left[n_{i j t} \ln \left(\sum_{i=1}^{I} \sum_{j=1}^{J} \sum_{t=1}^{T} \exp \left(\widetilde{x}_{i j t} \beta+\widetilde{\tau}_{i j t} \gamma+\delta_{j}\right)\right)\right]
\end{aligned}
$$

from which the coefficients $\beta$ and $\gamma$ can be estimated. 
In practice, a caveat against the conditional logit model is that it can require massive amounts of data for estimation. To avoid this caveat, Guimarães et al. (2003) have proposed to turn to the Poisson regression for the coefficient estimation in location choice models. This assumes that $n_{i j t}$ is Poisson distributed, that is $\operatorname{Prob}\left[n=n_{i j t}\right]=\left[\exp \left(-\lambda_{i j t}\right) \lambda_{j t}^{n_{i j t}}\right] / n_{i j t}$ ! whilst an exponential mean transformation connects the Poisson parameter $\lambda_{i j t}$ with the explanatory variables of (8), that is $E\left[n_{i j t}\right]=\lambda_{i j t}=\exp \left(\widetilde{x}_{i j t} \beta+\widetilde{\tau}_{i j t} \gamma+\delta_{i}+\delta_{j}+\delta_{t}\right)=\alpha_{i t} \exp \left(\widetilde{x}_{j t} \beta+\widetilde{\tau}_{i j t} \gamma+\delta_{j}\right)$. For our case with panel data, $\alpha_{i t}=\exp \left(\delta_{i}+\delta_{t}\right)$ absorbs the heterogeneity from different source countries and years and is here treated as fixed effect. Guimarães et al. (2003) have shown that the concentrated log-likelihood function, which no longer depends on $\alpha_{i t}$, equals

$$
\begin{aligned}
\ln L_{p c}= & \sum_{i=1}^{I} \sum_{j=1}^{J} \sum_{t=1}^{T} n_{i j t}\left(\widetilde{x}_{i j t} \beta+\widetilde{\tau}_{i j t} \gamma+\delta_{j}\right) \\
& -\sum_{i=1}^{I} \sum_{j=1}^{J} \sum_{t=1}^{T}\left[n_{i j t} \ln \left(\sum_{i=1}^{I} \sum_{j=1}^{J} \sum_{t=1}^{T} \exp \left(\widetilde{x}_{i j t} \beta+\widetilde{\tau}_{i j t} \gamma+\delta_{j}\right)\right)\right]+C .
\end{aligned}
$$

Since (11) differs from (10) only as regards the constant $C$, the estimates of $\beta$ and $\gamma$ of a Poisson regression and a conditional logit model are identical!

Owing to different asymptotic assumptions, in small samples, the standard deviations can differ between the logit model and the Poisson regression. However, Schmidheiny and Brülhart (2011, p. 219) show that clustering at the group level $\alpha_{i t}$ yields asymptotically identical SE. For our case with thousands of count variables that reflect many more location choices embodied in CBA deals, these asymptotic properties are likely to hold as long as the SE are appropriately clustered.

As long as the variables are transformed into logarithms, the coefficients ( $\beta$ and $\gamma$ ) of the Poisson regression have the interpretation of an elasticity with respect to the expected number of acquisitions $E\left[n_{i j t}\right]$. Hence, the (direct) tax elasticity $\eta$, given by

$$
\eta=\frac{\partial E\left[n_{i j t}\right]}{\partial \tau_{i j t}} \frac{\tau_{i j t}}{E\left[n_{i j t}\right]}=\gamma,
$$

is constant. ${ }^{27}$

\section{References}

Acemoglu, D., Johnson, S., \& Mitton, T. (2009). Determinants of vertical integration: Financial development and contracting costs. Journal of Finance, 63, 1251-1290.

\footnotetext{
27 Though the coefficient estimates are identical, Schmidheiny and Brülhart (2011) observe that the elasticities differ between the Poisson regression and the conditional logit model. In particular, the tax elasticity of the conditional logit model, which is $\eta_{i j t}^{c l}=\left(1-P_{i j t}\right) \gamma$, cannot be larger than (12). As long as $P_{i j t}$ is small, which tends to be the case in a samples comprising a large number of countries and years, the difference between the elasticity of a Poisson regression and a conditional logit model will be small.
} 
Alfaro, L., \& Charlton, A. (2009). Intra-industry foreign direct investment. American Economic Review, 99, 2096-2119.

Antràs, P., \& Yeaple, S. R. (2014). Multinational firms and the structure of international trade. In Gita Gopinath, Elhanan Helpman, \& Kenneth Rogoff (Eds.), Handbook of international economics (Vol. 4). Amsterdam: Elsevier.

Barrios, S., Huizinga, H., Laeven, L., \& Nicodème, G. (2012). International taxation and multinational firm location decisions. Journal of Public Economics, 96, 946-958.

Becker, J., \& Fuest, C. (2010). Taxing foreign profits with international mergers and acquisitions. International Economic Review, 51, 171-186.

Becker, J., \& Fuest, C. (2011). Source versus residence based taxation with international mergers and acquisitions. Journal of Public Economics, 95, 28-40.

Blonigen, B. (1997). Firm-specific assets and the link between exchange rates and foreign direct investment. American Economic Review, 87, 447-465.

Blonigen, B., \& Davies, R. (2004). The effects of bilateral tax treaties on US FDI Activity. International Tax and Public Finance, 11, 601-622.

Braconier, H., Norbäck, P. H., \& Urban, D. (2005). Multinational enterprises and wage cost: vertical FDI revisited. Journal of International Economics, 67, 446-470.

Buettner, T., \& Ruf, M. (2007). Tax incentives and the location of FDI: Evidence from the panel of German multinationals. International Tax and Public Finance, 14, 151-164.

Buettner, T., \& Wamser, G. (2009). Tax impact of nonprofit taxes on foreign direct investment: Evidence from German multinationals. International Tax and Public Finance, 14, 151-164.

Cameron, C. A., \& Trivedi, P. K. (1998). Regression analysis of count data. Cambridge: Cambridge University Press.

Coeurdacier, N., De Santis, R. A., \& Aviat, A. (2009). Cross-border mergers and acquisitions and European integration. Economic Policy, 57, 56-106.

Daude, C., \& Stein, E. (2007). The quality of institutions and foreign direct investment. Economics and Politics, 19, 317-344.

De Mooij, R., \& Ederveen, S. (2003). Taxation and foreign direct investment: A synthesis of empirical research. International Tax and Public Finance, 10, 673-696.

De Mooij, R., \& Ederveen, S. (2008). Corporate tax elasticities: A reader's guide to empirical findings. Oxford Review of Economic Policy, 24, 680-697.

Desai, M. A., Foley, C. F., \& Hines, J. R. (2004). Foreign direct investment in a world of multiple taxes. Journal of Public Economics, 88, 2727-2744.

Desai, M. A., \& Hines, J. R. (2005). Value added taxes and international trade. Mimeo: The Evidence.

Devereux, M.P. (2006). The impact of taxation on the location of capital, firms, and profit: A survey of empirical evidence. Oxford Centre For Business Taxation working paper 07/02.

Devereux, M., \& Griffith, R. (1998). Taxes and the location of production: Evidence from a panel of US multinationals. Journal of Public Economics, 68, 335-367.

Devereux, M., Griffith, R., \& Klemm, A. (2002). Corporate income tax: Reforms and tax competition. Economic Policy, 17, 449-495.

Di Giovanni, J. (2005). What drives capital flows? Activity and financial deepening. Journal of International Economics, 65, 127-149.

Djankov, S., Ganser, T., McLeish, C., Ramalho, R., \& Schleifer, A. (2010). The effect of corporate taxes on investment and entrepreneurship. American Economic Journal: Macroeconomics, 2, 31-64.

Erel, I., Liao, R. C., \& Weisbach, M. C. (2012). Determinants of cross-border mergers and acquisitions. The Journal of Finance, 68, 1045-1082.

Fan, J. P. H., \& Lang, L. H. P. (2000). The measurement of relatedness: An application to corporate diversification. Journal of Business, 73, 629-660.

Fan, J. P. H., \& Goyal, V. K. (2006). On the patterns and wealth effects of vertical mergers. Journal of Business, 97, 877-902.

Froot, K. A., \& Stein, J. C. (1991). Exchange rates and foreign direct investment: An imperfect capital markets approach. Quarterly Journal of Economics, 106, 1191-1217.

Garfinkel, J. A., \& Hankins, K. W. (2011). The role of management in mergers and merger waves. Journal of Financial Economics, 101, 515-532.

Guimarães, P., Figueirdo, O., \& Woodward, D. (2003). A tractable approach to the firm location decision problem. The Review of Economics and Statistics, 85, 201-204. 
Head, K., \& Ries, J. (2008). FDI as an outcome of the market for corporate control: Theory and evidence. Journal of International Economics, 74, 2-20.

Herger, N., Kotsogiannis, C., \& McCorriston, S. (2011). International taxation and FDI strategies: Evidence from US cross-border acquisitions. Economics Department discussion paper 11/09, University of Exeter.

Herger, N., Kotsogiannis, C., \& McCorriston, S. (2008). Cross-border acquisitions in the global food sector. European Review of Agricultural Economics, 35, 563-587.

Herger, N., \& McCorriston, S. (2013). On discrete location choice models. Economics Letters, 120, $288-291$.

Hijzen, A., Görg, H., \& Manchin, M. (2008). Cross-border mergers \& acquisitions and the role of trade costs. European Economic Review, 52, 849-866.

Huizinga, H. P., \& Voget, J. (2009). International taxation and the direction and volume of cross-border M\&As. Journal of Finance, 64, 1217-1249.

Huizinga, H. P., Voget, J., \& Wagner, W. (2012). Who bears the burden of international taxation? Evidence from cross-border M\&As. Journal of International Economics, 88, 186-197.

Keen, M., \& Syed, M. (2006). Domestic taxes and international trade: Some evidence, IMF working paper $\mathrm{WP} / 06 / 47$.

KPMG (various years). Corporate and Indirect Tax Survey.

La Porta, R., Lopez-De-Silanes, F., Shleifer, A., \& Vishny, R. W. (1998). Law and finance. Journal of Political Economy, 106, 1113-1155.

Mutti, J., \& Grubert, H. (2004). Empirical asymmetries in foreign direct investment and taxation. Journal of International Economics, 62, 337-358.

Rossi, S., \& Volpin, P. F. (2004). Cross-country determinants of mergers and acquisitions. Journal of Financial Economics, 74, 277-304.

Schmidheiny, K., \& Brülhart, M. (2011). On the equivalence of location choice models: Conditional logit, nested logit and Poisson. Journal of Urban Economics, 69, 214-222.

UBS (various years). Prices and Earnings around the globe, Zurich.

UNCTAD (2000). World Investment Report, Geneva.

Yeaple, S. R. (2003). The complex integration strategies of multinationals and cross country dependencies in the structure of foreign direct investment. Journal of International Economics, 60, 293-314.

ZEW (2008). Effective levels of company taxation within an enlarged EU. Study for the European Commission. 